Article

\title{
New Composite Sorbent for Removal of Sulfate Ions from Simulated and Real Groundwater in the Batch and Continuous Tests
}

\author{
Waqed Hassan ${ }^{1}\left(\mathbb{D}\right.$, Ayad Faisal ${ }^{2, *}$, Enas Abed ${ }^{1}$, Nadhir Al-Ansari ${ }^{3, *(\mathbb{D})}$ and Bahaa Saleh ${ }^{4}(\mathbb{D}$ \\ 1 Department of Civil Engineering, College of Engineering, University of Kerbala, Kerbala 56001, Iraq; \\ waaqidh@uokerbala.edu.iq (W.H.); eng.enas.hashim@gmail.com (E.A.) \\ 2 Environmental Engineering, College of Engineering, University of Baghdad, Baghdad 10001, Iraq \\ 3 Department of Civil, Environmental and Natural Resources Engineering, Lulea University of Technology, \\ 97187 Lulea, Sweden \\ 4 Mechanical Engineering Department, College of Engineering, Taif University, P.O. Box 11099, \\ Taif 21944, Saudi Arabia; b.saleh@tu.edu.sa \\ * Correspondence: ayadabedalhazafaisal@yahoo.com (A.F.); nadhir.alansari@ltu.se (N.A.-A.); \\ Tel.: +9647904208688 (N.A.-A.)
}

Citation: Hassan, W.; Faisal, A.;

Abed, E.; Al-Ansari, N.; Saleh, B. New Composite Sorbent for Removal of Sulfate Ions from Simulated and Real Groundwater in the Batch and Continuous Tests. Molecules 2021, 26, 4356. https://doi.org/10.3390/ molecules26144356

Academic Editor: João Valente Nabais

Received: 25 May 2021

Accepted: 9 July 2021

Published: 19 July 2021

Publisher's Note: MDPI stays neutral with regard to jurisdictional claims in published maps and institutional affiliations.

Copyright: (C) 2021 by the authors. Licensee MDPI, Basel, Switzerland. This article is an open access article distributed under the terms and conditions of the Creative Commons Attribution (CC BY) license (https:// creativecommons.org/licenses/by/ $4.0 /)$

\begin{abstract}
The evaluation of groundwater quality in the Dammam formation, Faddak farm, Karbala Governorate, Iraq proved that the sulfate $\left(\mathrm{SO}_{4}{ }^{2-}\right)$ concentrations have high values; so, this water is not suitable for livestock, poultry and irrigation purposes. For reclamation of this water, manufacturing of new sorbent for permeable reactive barrier was required through precipitation of $\mathrm{Mg}$ and Fe hydroxides nanoparticles on the activated carbon (AC) surface with best $\mathrm{Mg} / \mathrm{Fe}$ molar ratio of 7.5/2.5. Mixture of 50\% coated AC and 50\% scrap iron was applied to eliminate $\mathrm{SO}_{4}{ }^{2-}$ from contaminated water with efficiency of $59 \%$ and maximum capacity of adsorption equals to $9.5 \mathrm{mg} / \mathrm{g}$ for a time period of $1 \mathrm{~h}$, sorbent dosage $40 \mathrm{~g} / \mathrm{L}$, and initial $\mathrm{pH}=5$ at $50 \mathrm{mg} / \mathrm{L}_{\text {initial SO}}{ }_{4}{ }^{2-}$ concentration and $200 \mathrm{rpm}$ shaking speed. Characterization analyses certified that the plantation of $\mathrm{Mg}$ and Fe nanoparticles onto AC was achieved. Continuous tests showed that the longevity of composite sorbent is increased with thicker bed and lower influent concentration and flow rate. Computer solution (COMSOL) software was well simulated for continuous measurements. The reclamation of real contaminated groundwater was achieved in column set-up with efficiency of $70 \%$ when flow rate was $5 \mathrm{~mL} / \mathrm{min}$, bed depth was $50 \mathrm{~cm}$ and inlet $\mathrm{SO}_{4}{ }^{2-}$ concentration was $2301 \mathrm{mg} / \mathrm{L}$.
\end{abstract}

Keywords: scrap iron; sulfate ions; activated carbon; transport; permeable reactive barrier

\section{Introduction}

To maintain the quality of surface water and, consequently, the ecosystems, groundwater free of contamination is the target for several authorities and agencies that deal with water issues. Moreover, groundwater forms, in many countries, the major resource of potable water that is utilized by three out of four Europeans; Additionally, this water can be used for irrigation and industry. Spillage from gasoline storage tanks, landfills, leakage of septic tanks and accidental spills represent the point sources, while the distributed sources can be represented by infiltration of fertilizers, pesticides from agricultural regions and, in addition, contaminants in rain and snow [1].

Mostly, the detection of contamination in the groundwater needs a long time because the flow of this water is very slow and classified as a "laminar" regime. Thus, the implementation of remediation processes may be difficult and even not possible for certain locations, because the cost may exceed millions of dollars. Removing (or at least controlling) the source of contamination represents a significant step that must be applied before the remediation process. The cleanup can be achieved by one of the following methods [2,3]: containment of contaminants, pump and treat, stabilization/solidification, air stripping 
and natural attenuation. In addition, the permeable reactive barrier (PRB) method was presented as an alternative for treatment of polluted subsurface water and results of many studies proved that this method is effective and efficient in the reclamation of groundwater. Since the ending of the first decade from the present century, integration of the sustainability concepts and practices of green technology has been the aim of PRB studies, because it is considered by regulatory agencies as a key design element in almost every treatment strategy [4-9].

Sulfate forms the first or second most abundant anion in natural water resources [10]. Sulfur geo-chemistry represents the prime control for redox reactions of natural systems. Reduction of $\mathrm{SO}_{4}{ }^{2-}$ can occur extensively in the groundwater of subsurface systems. In such reduction, substantial quantity of $\mathrm{H}^{+}$can be consumed, accompanied with $\mathrm{HS}^{-}$production at ambient $\mathrm{pH}$ [11]. Popular techniques for $\mathrm{SO}_{4}{ }^{2-}$ elimination include: (i) Using sulfate-reducing bacteria in biological treatment, (ii) sorption processes and (iii) chemical precipitation [12]. High concentrations of $\mathrm{SO}_{4}{ }^{2-}$ ions result in severe problems for the environment, especially in the sectors of metallurgical, mining, chemical and agriculture [13]. Common examples of these problems include an alteration of water taste, troubles in digestion for humans and animals, acidification of soil and metals corrosion. Ions of $\mathrm{SO}_{4}{ }^{2-}$ are the prime contributor to water "mineralization", thereby increasing the conductivity and corrosion of the bodies of receptors [14].

Layered double hydroxides (LDHs), known as hydrotalcites, have a potential role in the treatment of a wide range of anionic, organic and inorganic chemicals [15-17]. LDHs are inorganic substances composed of stacked layers of positively charged metal cations with charge-balancing anions situated in the interlayer sites [18]. LDH is a layered anionic that can be connected via a non-covalent bond between non-framework interlayer anions and a positive main lamellar [19-21]. The surface precipitation with metal ions can be enhanced in the $\mathrm{LDH}$ due to availability of $\mathrm{OH}$ groups and the interlayer anions [22]. LDHs are a category of isostructural (2D) lamellar materials composed of brucite-like octahedral sheets with positive charges [23-26]. Magnesium/ferric-based LDH (MF-LDH) can be co-precipitated from $\mathrm{Mg}$ and Fe salts and are indeed very efficient and environmentally friendly sorbents/ion exchangers for anions in aqueous media [27-30]. The LDH can be used extensively in the treatment of wastewater contaminated with different chemicals [31]. $\mathrm{Mg}(\mathrm{OH})_{2}$ is an environmentally friendly solid material that recently gained great attention [32-34]. Fe oxide/hydroxide is also an environmentally benign solid material that has been investigated for removing phosphate from water [35,36]. Additionally, previous studies [37,38] demonstrated the long-term and environmentally safe application of iron-based oxyhydroxide adsorbents, including the competition between $\mathrm{SO}_{4}{ }^{2-}$, phosphate and other anions in the system. MF-LDH has a low risk of Fe(III) release into water; thus, the application of MF-LDH into water bodies is expected to be safe [39].

The usage of $\mathrm{AC}$ is frequently limited in the treatment of contaminated groundwater due to its high cost. Accordingly, the configuration of funnel and gate proposed by Suthersan (1999) [40] was applied for shallow groundwater using replaceable cassettes of carbon. Mixing of AC with other materials like zero-valent iron (ZVI) was an attempt that achieved to reduce the required amount (cost) of AC for treatment process [41]. In addition, the application of ZVI in remediation of groundwater was investigated at the University of Waterloo, Canada and then it had commercialized in 1992. The destructive nature through treatment processing represents the principal advantage of ZVI. This material depends on the destruction of pollutants through redox reaction, which means that the chemicals are destroyed in a redox reaction. Thus, the end-products are contained nontoxic compounds like de-chlorinated hydrocarbons, hydrogen gas and chloride in solution. This material is placed in reactive zone of a barrier; it readily oxidizes to create further electrons and surface coverage by oxygen radicals. The cations are then neutralized or driven to attach to these radicals that may be distributed over the sorbent surface in such a process called reduction. Additionally, the efficient removal of toxic metal ions from aqueous solutions was tested by using nanocomposite materials [42,43]. 
The groundwater is classified as sulfate water in the southern desert, southern region of Al-Jazira, and the strip near to the Iranian border in eastern Iraq due to the presence of gypsum rocks in the vertical and horizontal pathways of water; so, this water is not suitable for irrigation of all crops [44]. Accordingly, this study represents a good attempt for investigating the possibility of using PRB for reducing of $\mathrm{SO}_{4}{ }^{2-}$ ions concentration in the simulated and real groundwater to satisfy the requirements of irrigation and/or domestic uses.

The specific aims of this work are: (1) Providing an overview of groundwater quality in the Dammam formation, Faddak farm, Karbala desert, Iraq; (2) investigation of the possibility of manufacturing a new composite sorbent consisting of scrap iron and AC coated with magnesium/iron-LDH nanoparticles for remediation of simulated and real groundwater containing $\mathrm{SO}_{4}{ }^{2-}$ ions; (3) identification of mechanisms governing the sorption of $\mathrm{SO}_{4}{ }^{2-}$ ions onto a synthesized sorbent; (4) experimental monitoring of the spatial and temporal propagation of $\mathrm{SO}_{4}{ }^{2-}$ along the sorbent bed and finding the capability of COMSOL software in the simulation of the measurements.

\section{Study Area}

To simulate the real properties of groundwater, several samples of this water were collected from a certain site located somewhere $19 \mathrm{~km}$ south-western of Karbala Governorate center under the south coast of Al-Razzaza lake, Iraq. The site is located between latitudes $\left(43^{\circ} 52^{\prime} 44^{\prime \prime} \mathrm{N}\right)$, and longitudes $\left(32^{\circ} 43^{\prime} 23^{\prime \prime} \mathrm{E}\right)$ with gross area reaching to 2000 dunam. The main soil type of the aquifer in this area is sediments of gravel, sand and gravelly sand with presence of clayey lenses. The area has smooth topographic features with surface elevation ranging from 20 to $61 \mathrm{~m}$ above sea level, decreasing from north-east to south-west, with the presence of ten wells utilized to estimate the aquifer properties. The stratigraphic column consists of Tayarat, Umm Er Radhuma, Dammam, Euphrates, Nfayil, Fat'ha, Injana, Dibdibba and Quaternary Deposits arranged from oldest to newest. More information of the composition and characteristics of these formations is presented in previous literatures like [45].

\section{Models for Simulation of Experimental Measurements}

\subsection{Equilibrium Isotherm Models}

The sorption model is the expression correlated between the amount of contaminant loaded onto sorbent $\left(q_{e}, \mathrm{mg} / \mathrm{g}\right)$ and the concentration $\left(C_{e}, \mathrm{mg} / \mathrm{L}\right)$ remaining after the sorption process at a specific temperature and $\mathrm{pH}$ [46]. The utilized sorption models include [47]:

1. Freundlich model; Equation (1) can apply for multilayer sorption onto non-homogenous surfaces as follows:

$$
q_{e}=K_{F} C_{e}^{\frac{1}{n}}
$$

where $K_{F}$ is the constant of Freundlich and $1 / n(<1)$ is the intensity of sorption.

2. Langmuir model; Equation (2) applies for homogenous surfaces and monolayer sorption:

$$
q_{e}=\frac{q_{\max } b C_{e}}{1+b C_{e}}
$$

where $q_{\max }$ is the maximum capacity of adsorption $(\mathrm{mg} / \mathrm{g})$ and $b$ is the chemical intensity on the solid matrix.

\subsection{Kinetic Models}

The transfer rate of the dissolved contaminant from aqueous to solid phases is an essential parameter to design the sorption process [48]. This rate can be calculated from the following relationships: 
1. Pseudo first order:

$$
q_{t}=q_{e}\left(1-\mathrm{e}^{-k_{1} t}\right)
$$

where $q_{t}$ and $q_{e}(\mathrm{mg} / \mathrm{g})$ are the quantities of contaminant loaded on the solid particles at $t$ and equilibrium times, respectively, and $k_{1}$ is the rate constant $(1 / \mathrm{min})$.

2. Pseudo second order [49]:

$$
q_{t}=\frac{\mathrm{t}}{\left(\frac{1}{k_{2} q_{e}^{2}}+\frac{t}{q_{e}}\right)}
$$

where $k_{2}$ is the rate constant of this model ( $\left.\mathrm{g} / \mathrm{mg} \mathrm{min}\right)$.

\subsection{Transport of Solute}

The dissolved contaminant transport in the subsurface environment under the effects of advection, hydro-dynamic dispersion and sorption is expressed by the "advectiondispersion-reaction" equation. The derivation of this equation was achieved by combination of Fick's second law with the mass conservation equation. For uniform and steady velocities, the solute transport equation will be as follows for one-dimensional solute transport:

$$
D_{z} \frac{\partial^{2} C}{\partial z^{2}}-V_{z} \frac{\partial C}{\partial z}=\mathrm{R} \frac{\partial C}{\partial t}
$$

where $\mathrm{R}$ is the retardation factor that is calculated with aid of the isotherm model.

\section{Results and Discussion}

\subsection{Evaluation of Groundwater Quality}

Insightful vision about the quality of groundwater for any selected region can be conducted through the measurements of common water quality parameters like $\mathrm{pH}, \mathrm{EC}$, TDS, COD, anions and cations. However, as the target chemical adopted in this work was $\mathrm{SO}_{4}{ }^{2-}$ concentrations, the average spatial distribution of these ions for water samples collected from wells in the Faddak farm was changed nearly from 400 to $2100 \mathrm{mg} / \mathrm{L}$. It is clear that the $\mathrm{SO}_{4}{ }^{2-}$ ions had values that exceeded the allowable limit $(=250 \mathrm{mg} / \mathrm{L})$; so, the PRB with novel reactive material can be applied to restore this water for the mentioned limit. The manufactured material consisted of $\mathrm{AC}-(\mathrm{Mg} / \mathrm{Fe})-\mathrm{LDH}$ mixed with scrap iron.

\subsection{Preparation of Novel Sorbent}

Primary tests proved that the elimination of $\mathrm{SO}_{4}{ }^{2-}$ from water onto AC did not exceed $1 \%$; so, modification of AC by coating its surface with $(\mathrm{Mg} / \mathrm{Fe})-\mathrm{LDH}$ is required. The preparation process requires addition of $20 \mathrm{~g}$ AC to $200 \mathrm{~mL}$ of aqueous solution containing $\mathrm{Mg}\left(\mathrm{NO}_{3}\right)_{2} \cdot 6 \mathrm{H}_{2} \mathrm{O}$ and $\mathrm{FeCl}_{3} \cdot 6 \mathrm{H}_{2} \mathrm{O}$ with ratios of $10 / 0,7.5 / 2.5,5 / 5,2.5 / 7.5$ and 0/10, respectively. The performance of prepared $\mathrm{AC}-(\mathrm{Mg} / \mathrm{Fe})-\mathrm{LDH}$ was evaluated through finding the removal of $\mathrm{SO}_{4}{ }^{2-}$ ions by applying $2 \mathrm{~g}$ sorbent to $50 \mathrm{~mL}$ of contaminated water with $C_{o}$ of $50 \mathrm{mg} / \mathrm{L}$, speed of $200 \mathrm{rpm}$, initial pH of 7, and time of $3 \mathrm{~h}$. Figure 1a explains the outputs of sorption tests where there is a dramatic variation in the removal efficiencies as a function of $\mathrm{Mg}\left(\mathrm{NO}_{3}\right)_{2} \cdot 6 \mathrm{H}_{2} \mathrm{O}$ and $\mathrm{FeCl}_{3} \cdot 6 \mathrm{H}_{2} \mathrm{O}$ ratio. This figure signifies that the best ratio is $7.5 / 2.5$, which lead to maximum removal efficiency $(\approx 35.5 \%)$; however, increasing or decreasing of the ratio from this value will cause an obvious decrease in the efficiency and the lowest value $(\approx 1.5 \%)$ appeared at the ratio of $0 / 10$. To improve the elimination of $\mathrm{SO}_{4}{ }^{2-}$ from water, the scrap iron was mixed with $\mathrm{AC}-(\mathrm{Mg} / \mathrm{Fe})-\mathrm{LDH}$. A group of batch tests were implemented at the same operational conditions mentioned previously to specify the best weight ratio of coated AC to scrap iron, and results are illustrated in Figure 1b. It seems that the variation of ratio from $10 / 0$ to $5 / 5$ will be accompanied with an increase of efficiency from $35.5 \%$ to $59.0 \%$, respectively; however, clear reduction in the efficiency can be observed beyond the ratio of $5 / 5$ to be $37.5 \%$ at $0 / 10$. All next batch and continuous tests must be conducted with reactive material consisting of mixing AC-(Mg/Fe)-LDH and scrap iron with a proportion of $5 / 5$. 

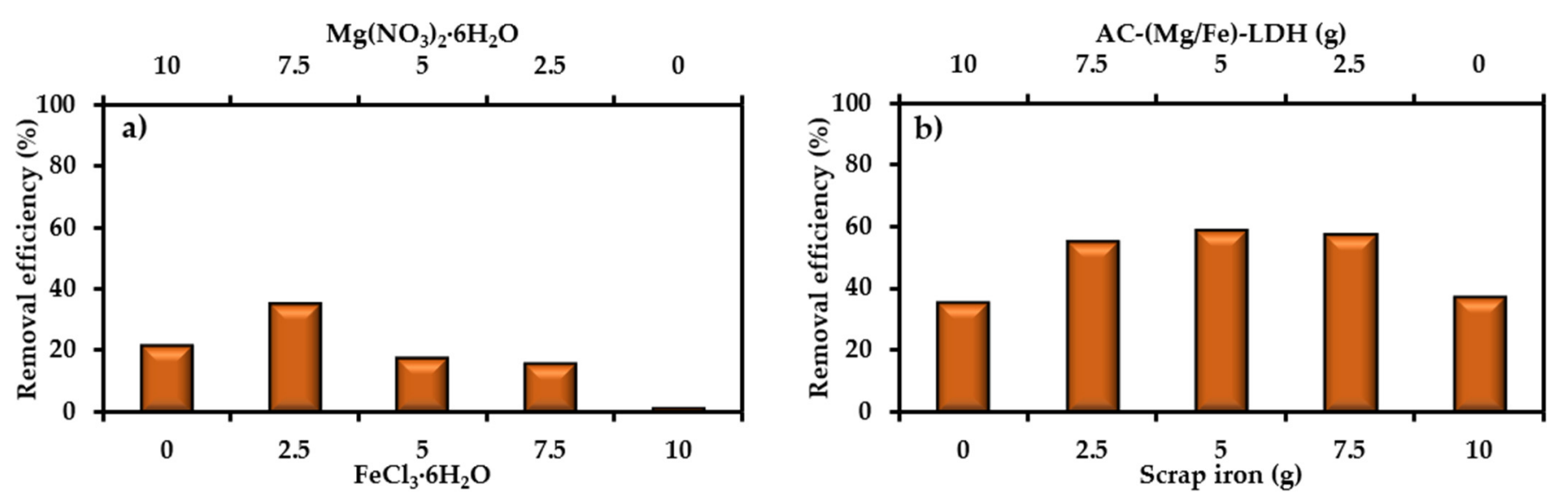

Figure 1. Removal efficiency of $\mathrm{SO}_{4}{ }^{2-}$ ions from contaminated water onto (a) AC-(Mg/Fe)-LDH for different weight ratios of $\mathrm{Mg}\left(\mathrm{NO}_{3}\right)_{2} \cdot 6 \mathrm{H}_{2} \mathrm{O}$ and $\mathrm{FeCl}_{3} \cdot 6 \mathrm{H}_{2} \mathrm{O}$ and $(\mathbf{b})$ mixture of $\mathrm{AC}-(\mathrm{Mg} / \mathrm{Fe})-\mathrm{LDH}$ and scrap iron.

\subsection{Effect of Operation Variables in Batch Experiments \\ 4.3.1. Time and Initial Concentration}

The determination of equilibrium time is required for the batch study; so, the sorption onto adsorbent must be monitored with contact time. For initial pH 7 and speed of $200 \mathrm{rpm}$, sorbent (mixture of AC-(Mg/Fe)-LDH and scrap iron) dosage of $2 \mathrm{~g}$ was mixed with $50 \mathrm{~mL}$ of aqueous solution contaminated with an initial $\mathrm{SO}_{4}{ }^{2-}$ concentration of 50, 100, 150 and $200 \mathrm{mg} / \mathrm{L}$, at room temperature for a contact time not greater than $3 \mathrm{~h}$. For any value of $C_{0}$, Figure 2a signifies that the sorption rate of $\mathrm{SO}_{4}{ }^{2-}$ can increase rapidly in initial times and is slowed beyond $1 \mathrm{~h}$ because of the reduction of binding sites. The same figure illustrates that the removal efficiencies of $\mathrm{SO}_{4}{ }^{2-}$ were decreased drastically due to the increase of $\mathrm{C}_{0}$. This variation may have resulted from the saturation of vacant sites interacting with $\mathrm{SO}_{4}{ }^{2-}$ It seems that the removal of $\mathrm{SO}_{4}{ }^{2-}$ was $50.32 \%$ at the equilibrium time of $1 \mathrm{~h}$ for $\mathrm{C}_{o}$ of $50 \mathrm{mg} / \mathrm{L}$; however, this efficiency will decrease to be $10.78 \%$ for $C_{o}$ of $200 \mathrm{mg} / \mathrm{L}$ for the same time. At equilibrium, results signified that there is a rapid increment in the quantity of sorbed contaminant onto sorbent in the low ranges of $C_{0}$. This quantity is growing in a gradual scheme due to the increase of $C_{0}$, causing an improvement in drive force for the transference of ions from liquid to solid phases; thus, a decline in the removal rate can be observed with the rise of $C_{o}$.

\subsubsection{Initial $\mathrm{pH}$}

The influence of $\mathrm{pH}$ in the removal of $\mathrm{SO}_{4}{ }^{2-}$ onto prepared sorbent was examined in the range from 2.0 to 12.0 at a speed of $200 \mathrm{rpm}, \mathrm{C}_{o}$ of $50 \mathrm{mg} / \mathrm{L}$, dosage of $2 \mathrm{~g} / 50 \mathrm{~mL}$ and time of $1 \mathrm{~h}$ (Figure $2 \mathrm{~b}$ ). The maximum adsorption of $\mathrm{SO}_{4}{ }^{2-}$ ions $(=56 \%)$ occurred at $\mathrm{pH}$ 5. For $\mathrm{pH}<5$, the high electrostatic force of repulsion shows between the negative charged surface of sorbent and the negatively charged ions of $\mathrm{SO}_{4}{ }^{2-}$, and this caused a clear decrease in the $\mathrm{SO}_{4}{ }^{2-}$ uptake. This means that the increase of negatively charged sites in the adsorbent is not favorable for the uptake of $\mathrm{SO}_{4}{ }^{2-}$ due to the generation of repulsion forces. At higher $\mathrm{pH}$, hydroxyl ions are effectively increased and, consequently, a remarkable decrease in removal $\mathrm{SO}_{4}{ }^{2-}$ ions can be observed. The $\mathrm{pH}$ change results in the dissociation of working groups of the sorbent, which lead to a shift in the equilibrium sorption properties. This can be explained in detail by measuring the point zero charge $\left(\mathrm{pH}_{\mathrm{pzc}}\right)$ of sorbent. Theoretically, $\mathrm{pH}_{\mathrm{pzc}}$ is generally described as the $\mathrm{pH}$ value at which the net charge at a sorbent surface equals to zero (i.e., total positive charges $=$ total negative charges). This phenomenon will be useful in hypothesizing the ionization mode of functional groups and the pattern of their interaction with other chemical substances in solution. In solutions with $\mathrm{pH}$ values lower than $\mathrm{pH}_{\mathrm{pzc}}$, surfaces of solid particles are negatively charged (Figure 2c) and; therefore, they have the ability to interact with positively charged ions. While at $\mathrm{pH}$ values higher than $\mathrm{pH}_{\mathrm{pzc}}$, the process description is the other way round. 
The "solid addition method" needed to be applied to find the zeta potential for the present sorbent, where $\mathrm{pH}_{\mathrm{pzc}}$ is approximately equal to 4.5 , as is obvious in Figure 2c. Accordingly, remaining tests were operated at $\mathrm{pH} 5\left(>\mathrm{pH}_{\mathrm{pzc}}\right)$ to ensure achievement of the maximum removal efficiency. At this $\mathrm{pH}$ level, being $>\mathrm{pH}_{\mathrm{pzc}}$, the sorbent surface has a positive charge, which forms an electrostatic attraction with negative ions. When the $\mathrm{pH}$ of water is smaller than $\mathrm{pH}_{\mathrm{pzc}}$, the sorbent surface has negative charges; so, it repels the negative ions. Thus, the maximum removal of $\mathrm{SO}_{4}{ }^{2-}$ ions occurred at an acidic $\mathrm{pH}$ of 5 , and this result is in line with findings of previous literatures in which the maximum uptake for these ions occurred in an acidic environment with $\mathrm{pH}$ ranging from 3 to 6 [50-52].

\subsubsection{Sorbent Mass}

The sorbent mass was changed from 0.5 to $5 \mathrm{~g} / 50 \mathrm{~mL}$ and the removal efficiencies of $\mathrm{SO}_{4}{ }^{2-}$ ions were determined through the measurement of equilibrium concentration. The effect of sorbent dosage was studied under $C_{0}, \mathrm{pH}$, time and shaking speed of $50 \mathrm{mg} / \mathrm{L}$, 5, $1 \mathrm{~h}$ and $200 \mathrm{rpm}$, respectively. The measurements are plotted in Figure 2d, where the removal percentages of $\mathrm{SO}_{4}{ }^{2-}$ ions are increased significantly with the increase of sorbent dosage. This increase is a logical trend, because the presence of a high amount of sorbent leads to more vacant sites for the interaction and capture of ions [53]. Results confirmed that the usage of $2 \mathrm{~g}$ of prepared sorbent can achieve the maximum removal of $\mathrm{SO}_{4}{ }^{2-}$ ions. It is important to calculate the mass of $\mathrm{SO}_{4}{ }^{2-}$ desorbed from exhausted sorbent; so, the desorption test was applied using washing reagent (represented by deionized water). Results demonstrated that the $\mathrm{SO}_{4}{ }^{2-}$ concentration in the washing solution was less than $2.3 \mathrm{mg} / \mathrm{L}$ at specified periods, with a total duration of $48 \mathrm{~h}$. This means that the present target contaminant is incorporated with the prepared sorbent by strong forces; consequently, this sorbent has an effective property in the retention of $\mathrm{SO}_{4}{ }^{2-}$ ions.
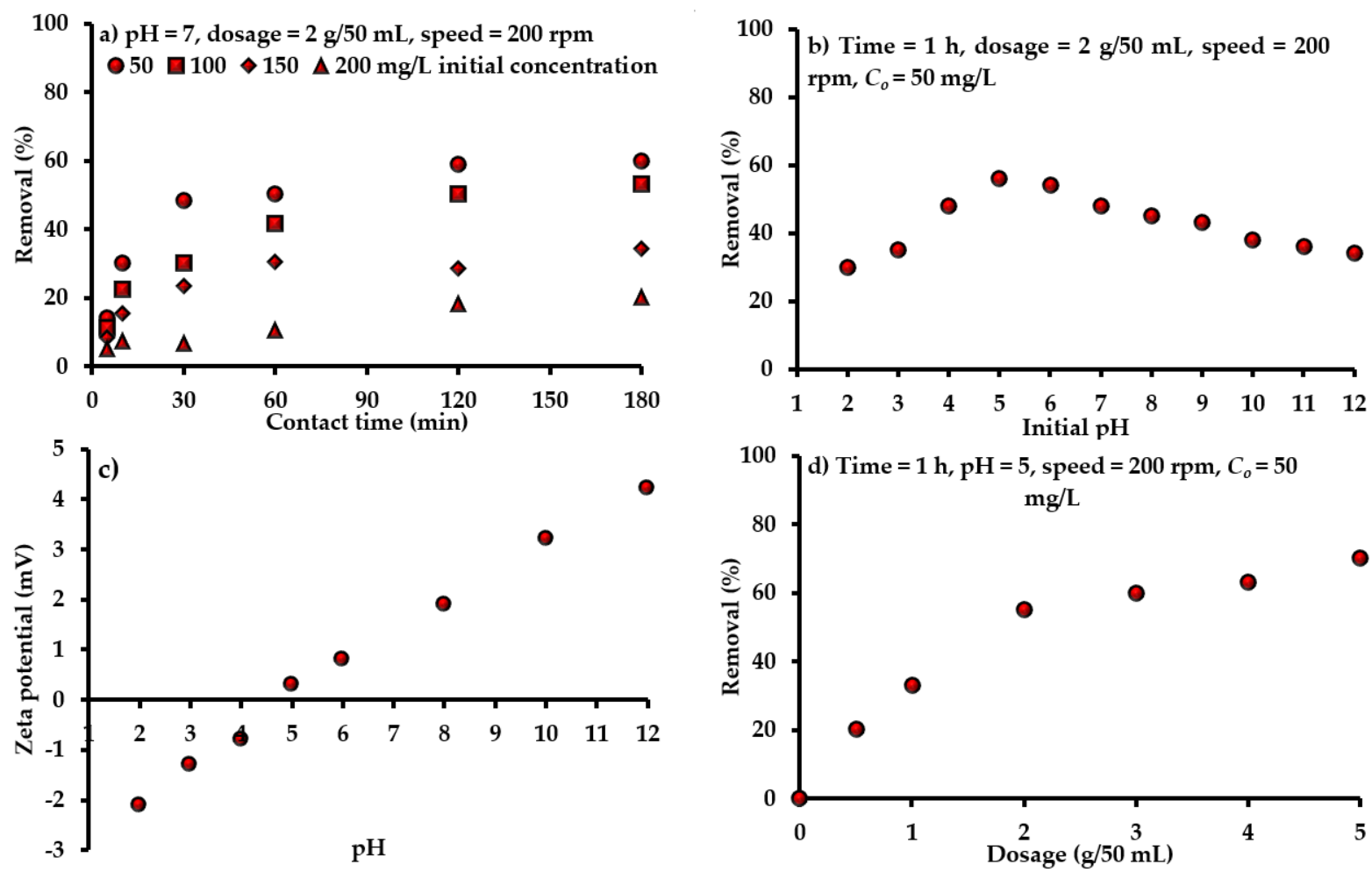

Figure 2. Influence of $(\mathbf{a})$ time and $C_{0},(\mathbf{b}, \mathbf{c}) \mathrm{pH}$ and $(\mathbf{d})$ sorbent dosage on the efficacy of prepared composite sorbent under different operational conditions. 


\subsection{Sorption Isotherm and Kinetics Models}

To find the suitable design for sorption system, the isotherm models for equilibrium sorption data must be determined. A set of equilibrium sorption tests for interaction of sulfate-water with $\mathrm{AC}-(\mathrm{Mg} / \mathrm{Fe})-\mathrm{LDH}$ mixed with scrap iron was conducted at $\mathrm{pH} 5, \mathrm{C}_{o}$ of $50 \mathrm{mg} / \mathrm{L}$, sorbent dosage in the range of $0.5-5 \mathrm{~g}$ for each $50 \mathrm{~mL}$, and speed of $200 \mathrm{rpm}$ for time of $1 \mathrm{~h}$. The outputs of these tests are simulated by models of Freundlich and Langmuir using nonlinear fitting in Microsoft Excel 2016 by applying "Solver" formula. The parameters of these models with statistical measures resulted from the fitting process were inserted in Table 1 . It seems that the $\left(q_{\max }\right)$ was $9.5 \mathrm{mg} / \mathrm{g}$ and $(b)$ was $0.0028 \mathrm{~L} / \mathrm{mg}$; however, the $\left(K_{f}\right)$ and $(1 / n)$ had values of $0.0319(\mathrm{mg} / \mathrm{g})(\mathrm{L} / \mathrm{mg})^{1 / n}$ and 0.8963 , respectively. Figure 3a shows the concurrence between the predicted curves of isotherm models and measured data. Each value of $q_{e}$ in this figure represents the average of three readings; however, the standard deviation for these readings must be calculated and plotted in the same figure as "error bars". It is clear that the two isotherms are well described by the

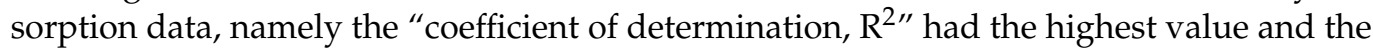
"sum of squared errors, SSE" had the lowest value $[54,55]$. The $(1 / n)$ is smaller than unity; so, there is favorable adsorption for $\mathrm{SO}_{4}{ }^{2-}$ ions onto the prepared sorbent. It seems that the $q_{\max }(=9.5 \mathrm{mg} / \mathrm{g})$ is comparable with those reported for AC derived from coconut coir pith $(4.9 \mathrm{mg} / \mathrm{g})$ [56] and from Lotus leaf $(9.3 \mathrm{mg} / \mathrm{g})$ [52].

The results of kinetic tests conducted to find the time effect on removal efficiency of $\mathrm{SO}_{4}{ }^{2-}$ ions from water were simulated by kinetic models for $C_{0}$ of $50 \mathrm{mg} / \mathrm{L}$. The constants of these models were calculated through fitting with experimental measurements using non-linear relationship_-"Solver" application-in Microsoft Excel 2016. The statistical measures for evaluating the concurrence between the predicted and measured data with kinetic constants are inserted in Table 1. This table certifies that the second model is more dependable for describing ions sorption from the aqueous solution, because $\mathrm{R}^{2}>0.97$ and SSE $=0.0058$. Additionally, the $\left(q_{e}\right)$ of $\mathrm{SO}_{4}{ }^{2-}$ is approached from experimental quantity and this certified the applicability of the mentioned model. Accordingly, the chemisorption must be the dominant mechanism. However, the degree of matching between the measurements and predictions of models can be observed in Figure $3 \mathrm{~b}$.

Table 1. Constants of equilibrium and kinetic models for removal of $\mathrm{SO}_{4}{ }^{2-}$ ions from contaminated water onto the prepared sorbent.

\begin{tabular}{|c|c|c|}
\hline Model & Parameter & Value \\
\hline \multirow{3}{*}{ Freundlich } & $K_{F}(\mathrm{mg} / \mathrm{g})(\mathrm{L} / \mathrm{mg})^{1 / n}$ & 0.0319 \\
\hline & $1 / n$ & 0.8963 \\
\hline & $\mathrm{R}^{2}, \mathrm{SSE}$ & $0.9253,0.0430$ \\
\hline \multirow{3}{*}{ Langmuir } & $q_{\max }(\mathrm{mg} / \mathrm{g})$ & 9.5 \\
\hline & $b(\mathrm{~L} / \mathrm{mg})$ & 0.0028 \\
\hline & $\mathrm{R}^{2}, \mathrm{SSE}$ & $0.9265,0.0222$ \\
\hline \multirow{4}{*}{ Pseudo first-order } & $q_{\exp .}(\mathrm{mg} / \mathrm{g})$ & 0.7700 \\
\hline & $k_{1}\left(\min ^{-1}\right)$ & 0.0653 \\
\hline & $q_{e}(\mathrm{mg} / \mathrm{g})$ & 0.7224 \\
\hline & $\mathrm{R}^{2}, \mathrm{SSE}$ & $0.9656,0.0087$ \\
\hline \multirow{3}{*}{ Pseudo second-order } & $k_{2}(\mathrm{~g} / \mathrm{mg} \min )$ & 0.0963 \\
\hline & $q_{e}(\mathrm{mg} / \mathrm{g})$ & 0.8072 \\
\hline & $\mathrm{R}^{2}, \mathrm{SSE}$ & $0.9782,0.0058$ \\
\hline
\end{tabular}



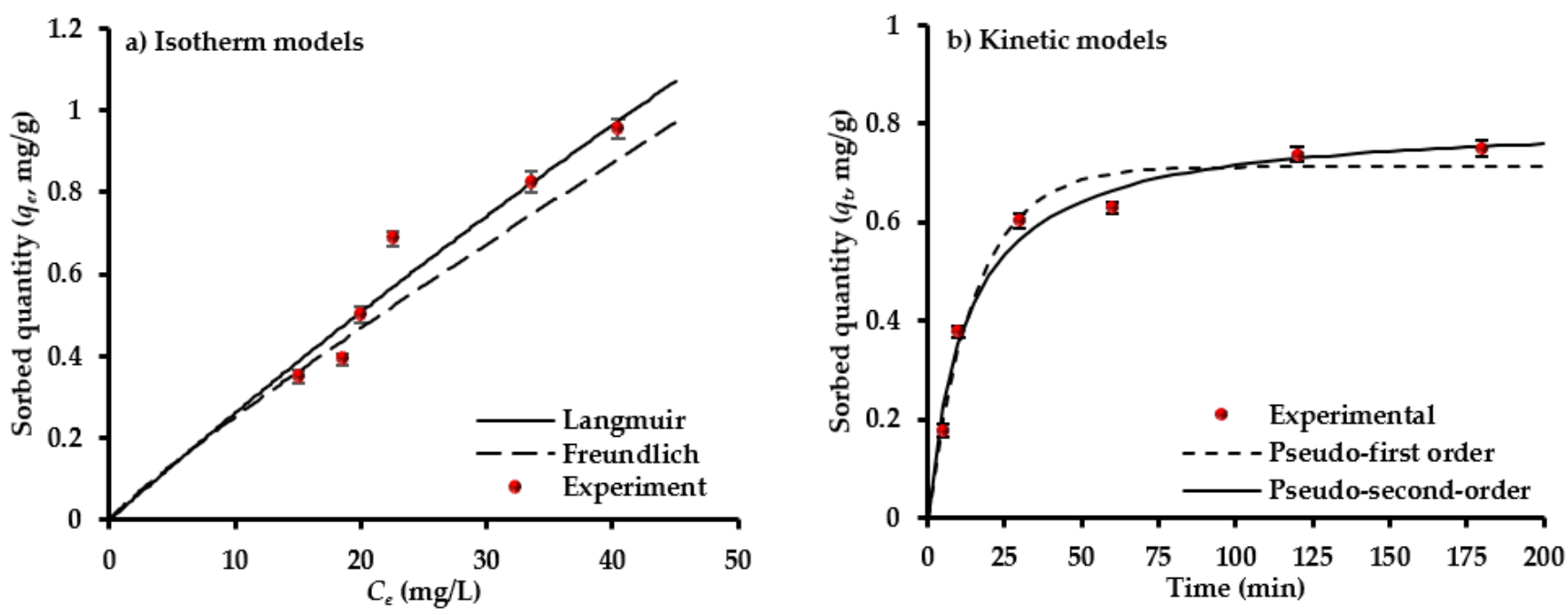

Figure 3. Sorption isotherms (a) and kinetics models (b) for the interaction of composite sorbent and solution containing $\mathrm{SO}_{4}{ }^{2-}$ ions.

\subsection{Characterization of Composite Sorbent}

The XRD analysis (Figure 4a) illustrates the composition of immobilized matrix (i.e., $\mathrm{AC})$ before and after precipitation of $(\mathrm{Mg} / \mathrm{Fe})-\mathrm{LDH}$ nanoparticles. According to standards of Joint Committee on Powder Diffraction, this figure elucidates the existence of diffraction reflection at $\left(2 \theta=23^{\circ}\right)$ for AC corresponding to carbon; however, graphite appeared at reflections $\left(2 \theta=24,26,44\right.$, and $\left.65^{\circ}\right)$ for $\mathrm{AC}-(\mathrm{Mg} / \mathrm{Fe})-\mathrm{LDH}$. In addition, the peaks $\left(2 \theta=11^{\circ}\right)$ for $\mathrm{AC}-(\mathrm{Mg} / \mathrm{Fe})-\mathrm{LDH}$ confirm the existence of hydrotalcite-like compounds which are composed of $\mathrm{Mg}$ and Fe [57]. The mentioned reflections represent the new sites generated on the AC surface, which increased the affinity of the coated material towards $\mathrm{SO}_{4}{ }^{2-}$ ions.

Infrared spectroscopy identified the functional groups and chemical structure before and after interaction with $\mathrm{SO}_{4}{ }^{2-}$ ions, whereby these groups are illustrated in Figure $4 \mathrm{~b}$. The available spectrum is very identical to that of lignocellulosic, like rockrose and pistachionut shell [58]. The $\mathrm{C}-\mathrm{H}$ vibrations in methylene and methyl groups can be corresponded to the band at $2929 \mathrm{~cm}^{-1}$. The band at $1662 \mathrm{~cm}^{-1}$ is attributed to groups of carbonyl C O. The vibrations of olefinic (C C) lead to the emergence of the band at $1651 \mathrm{~cm}^{-1}$, while two bands at 1511 and $1429 \mathrm{~cm}^{-1}$ can generate due to the skeletal $C \mathrm{C}$ vibrations in aromatic rings. The vibrations at 1463 and $1376 \mathrm{~cm}^{-1}$ are assigned to the bands $-\mathrm{CH}_{3}$ and $-\mathrm{CH}_{2}-$ [59]. In carboxylate groups, the band at $1323 \mathrm{~cm}^{-1}$ can attribute to $\mathrm{C}-\mathrm{O}$ vibrations. The band at $1246 \mathrm{~cm}^{-1}$ may attribute to esters, ethers or phenol groups. The relatively intense band at $1043 \mathrm{~cm}^{-1}$ can be assigned to alcohol groups (R-OH). The C-H out-of-plane bending in benzene derivative vibrations causes the band at $891 \mathrm{~cm}^{-1}$. The changes in the FT-IR spectra for the sorbent sample after the sorption process can be observed in Figure $4 \mathrm{~b}$. The sample exhibits the $\mathrm{OH}$ stretching vibrations band $\left(3600-3100 \mathrm{~cm}^{-1}\right)$ of surface hydroxylic groups and chemisorbed water. The asymmetry of this band at lower wavenumbers reveals the existence of strong $\mathrm{H}$ bonds between sorbed molecules of water and surface functional groups. The FT-IR spectra $\left(<2000 \mathrm{~cm}^{-1}\right)$ of the carbon sample demonstrate ideal absorption of structural and surface oxygen species. The bands (i) $1730-1705 \mathrm{~cm}^{-1}$ and (ii) $1570-1550 \mathrm{~cm}^{-1}$ ranges can, respectively, attribute to the C-O moieties stretching vibrations in (i) lactonic, ester, carboxylic or anhydride groups and (ii) conjugated systems like ketoesters, diketone and keto-enol structures [60]. Since water can sorb on the AC surface and non-specific interactions (physical sorption), the bands $\left(1500-1600 \mathrm{~cm}^{-1}\right) \mathrm{can}$ be described by overlapped $\mathrm{OH}$ binding vibrations. The complex nature of bands in the bands (1650-1500 $\mathrm{cm}^{-1}$ ) suggests that double bond (C-C) vibrations and aromatic ring bands overlap the $\mathrm{OH}$ binding vibration bands and aforesaid $\mathrm{C}-\mathrm{O}$ stretching vibration bands. A broad band $\left(1470-1380 \mathrm{~cm}^{-1}\right)$ is composed of sets of overlapping absorption 
bands ascribable to the deformation vibration of surface $\mathrm{OH}$ groups and in-plane vibrations of $\mathrm{C}-\mathrm{H}$.
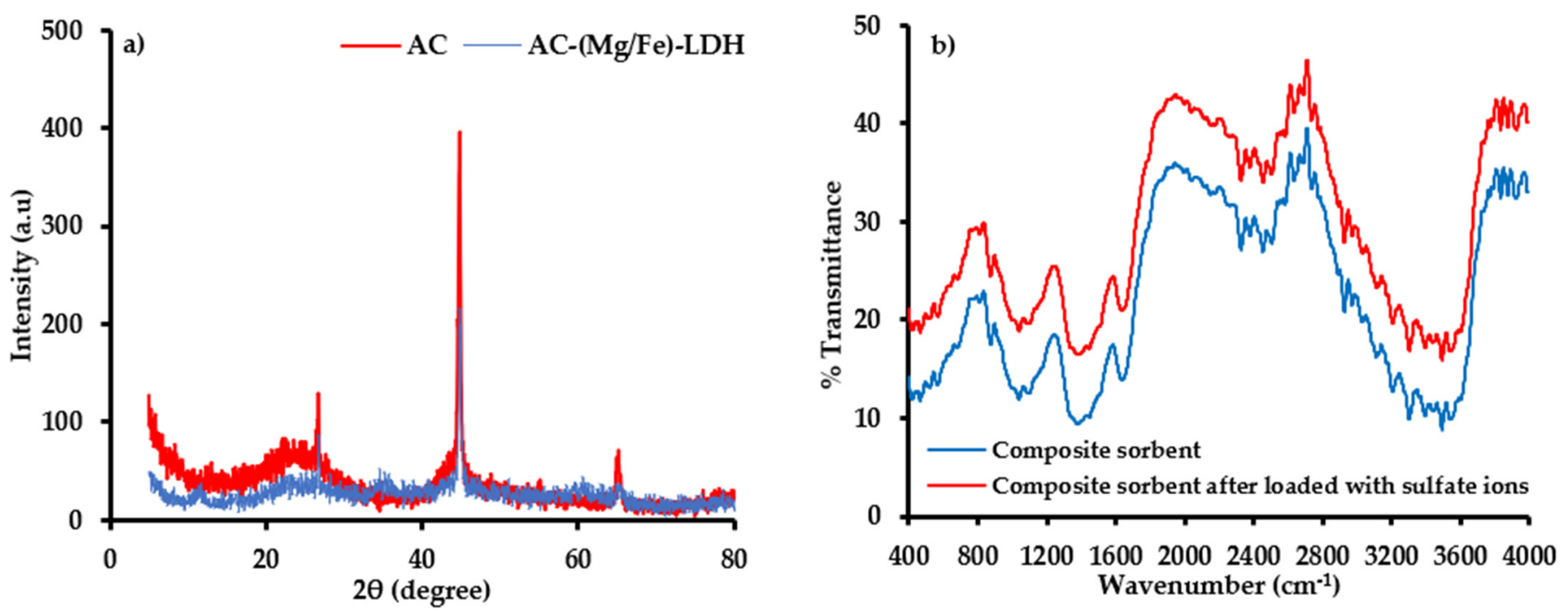

Figure 4. (a) Pattern of XRD for structure of AC and AC-(Mg/Fe)-LDH and (b) FT-IR test for (scrap iron + AC-(Mg/Fe)-LDH) sorbent before and after interaction with $\mathrm{SO}_{4}{ }^{2-}$ ions.

Energy-dispersive X-ray spectroscopy (EDS) gives elemental compositional graphs for $\mathrm{AC}$ and composite sorbent (scrap iron + AC-(Mg/Fe)-LDH), as illustrated in Figure 5. This figure with Table 2 elucidates that the carbon forms the predominant element in the composition of AC with a percentage of $90.72 \%$, and this is consistent with outputs of XRD analysis. Additionally, other elements, specifically $\mathrm{O}, \mathrm{Al}, \mathrm{Si}, \mathrm{S}$ and $\mathrm{Fe}$, with certain percentages can be observed in the AC composition. The table proves that the virgin AC is free of $\mathrm{Mg}$, while the percentage of Fe reached to $0.62 \%$. It seems that the percentage of Fe is increased drastically in the composite sorbent, to be $9.49 \%$ in comparison with $1.03 \%$ of $\mathrm{Mg}$, and this due to the use of Fe in the coating of AC and the addition of scrap iron. Results documented that the percentage of $\mathrm{S}$ was increased to become $1.34 \%$ in the composite sorbent after elimination of $\mathrm{SO}_{4}{ }^{2-}$ from water and this certifies the occurrence of adsorption.

For $500 \mathrm{~nm}$ magnification scale, SEM images (Figure 6) are important for identification of the morphological properties for adopted matters after and before contact with $\mathrm{SO}_{4}{ }^{2-}$ ions. It can be seen that the shape of the virgin $\mathrm{AC}$ is irregular and nanoparticles of $\mathrm{Mg} / \mathrm{Fe}$ can be recognized on the composite sorbent. The attachment of these nanoparticles on the AC surfaces made it coarse, sinuous and rougher, which is in line with surface areas determined from BET test. The surface area of AC is equal to $54 \mathrm{~m}^{2} / \mathrm{g}$ and this value can be increased to be $80.3 \mathrm{~m}^{2} / \mathrm{g}$ after coating. Obvious variations can be observed in the morphology of the composite sorbent beyond sorption process due to the attachment of $\mathrm{SO}_{4}{ }^{2-}$ ions. 

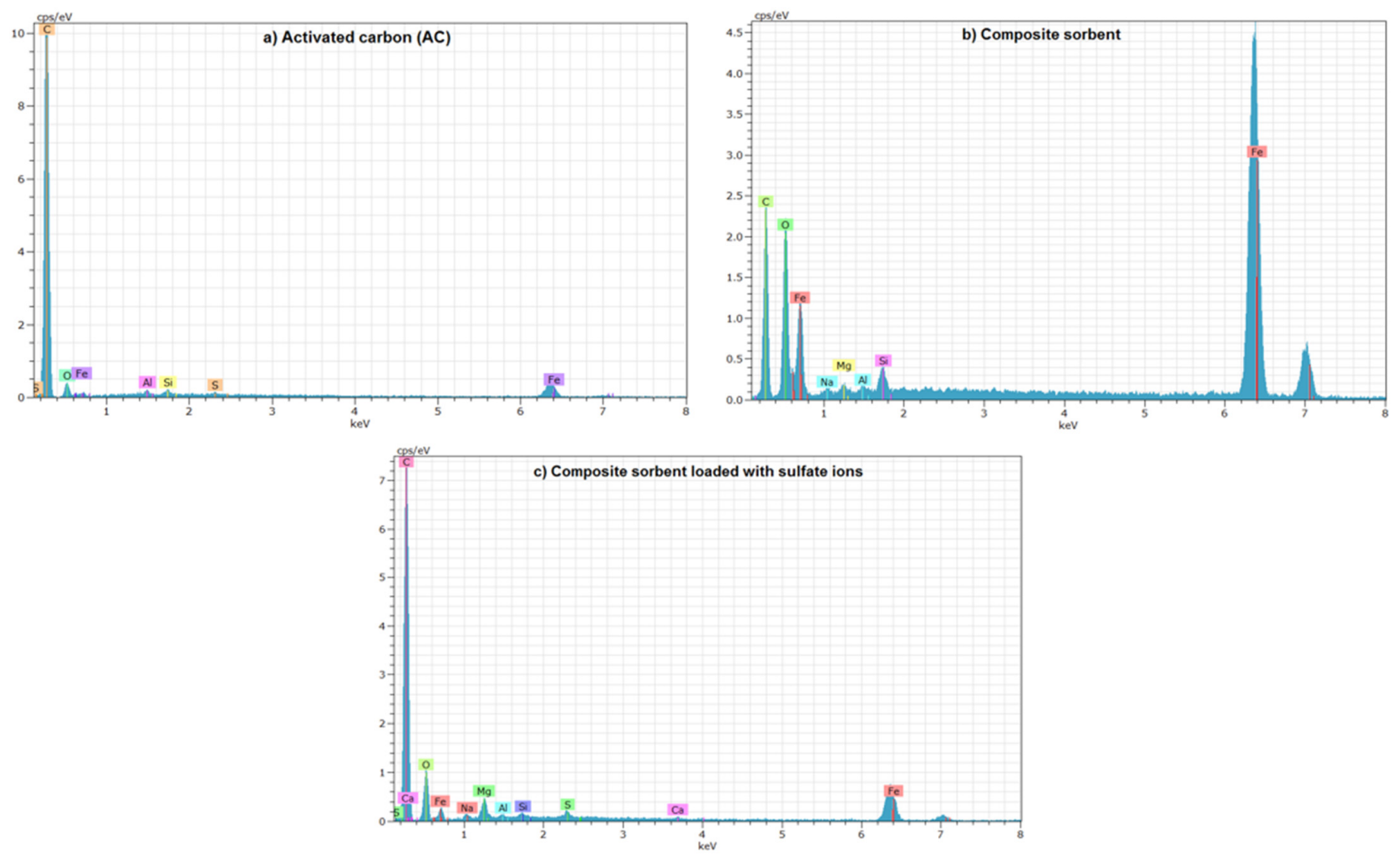

Figure 5. EDS spectrum of (a) AC, (b) composite sorbent before sorption and (c) composite sorbent after sorption of $\mathrm{SO}_{4}{ }^{2-}$ ions.
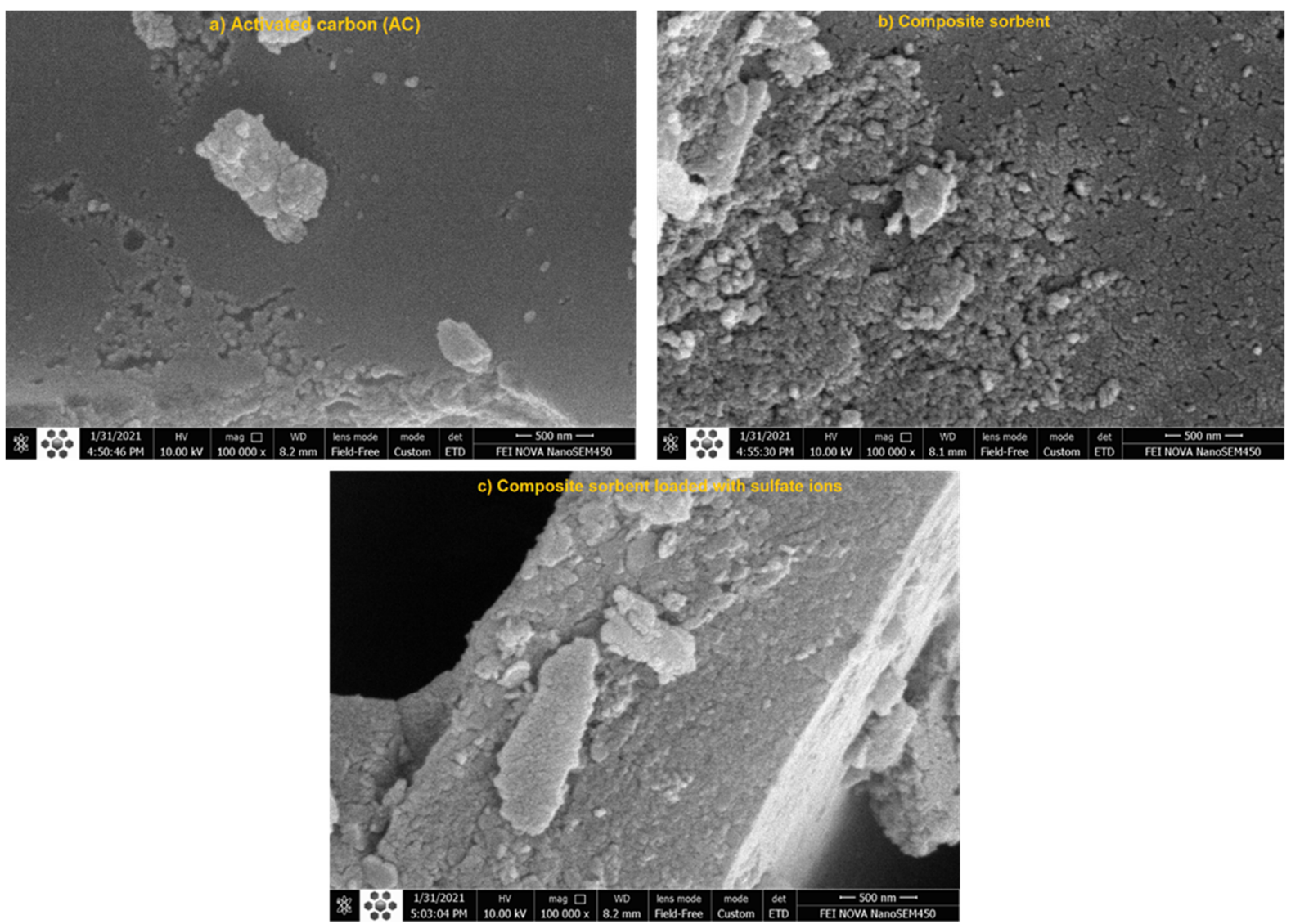

Figure 6. Images from SEM analysis for (a) AC, (b) composite sorbent before sorption and (c) composite sorbent after sorption of $\mathrm{SO}_{4}{ }^{2-}$ ions at $500 \mathrm{~nm}$ magnification scale. 
Table 2. Percentages of elements in the AC and composite sorbent before and after sorption of $\mathrm{SO}_{4}{ }^{2-}$ ions specified by EDS analysis.

\begin{tabular}{cccc}
\hline \multirow{2}{*}{ Element (\%) } & \multirow{2}{*}{ AC } & \multicolumn{2}{c}{ Composite Sorbent } \\
\cline { 3 - 4 } & & Before Sorption & After Sorption \\
\hline $\mathrm{C}$ & 90.72 & 56.14 & 79.25 \\
\hline $\mathrm{O}$ & 8.5 & 32.75 & 18.69 \\
\hline $\mathrm{Mg}$ & 0.0 & 1.03 & 0.56 \\
\hline $\mathrm{Al}$ & 0.07 & 0.17 & 0.05 \\
\hline $\mathrm{Si}$ & 0.06 & 0.42 & 0.05 \\
\hline $\mathrm{S}$ & 0.03 & 0 & 1.34 \\
\hline $\mathrm{Fe}$ & 0.62 & 9.49 & 1.05 \\
\hline
\end{tabular}

\subsection{Dispersion Coefficient}

For finding the relationship between the dispersion coefficient in the longitudinal direction $\left(D_{L}\right)$ and seepage velocity $(V)$, tracer experiments mentioned previously were conducted in the column filled with composite sorbent (scrap iron + AC-(Mg/Fe)-LDH). The tests were achieved at 5,10,15 and $20 \mathrm{~mL} / \mathrm{min}$ to ensure the flow regime in the porous medium was laminar with Reynolds number $(\operatorname{Re})<1-10$. This type of flow is a popular regime in the groundwater flow, as mentioned by [61]. The experimental measurements are plotted and represented in the form of a linear relationship (Equation 6 correlated between $D_{L}$ and $V$; however, this equation is identical to Equation (7):

$$
\begin{gathered}
D_{L}=3.7386 V+0.367, \quad R^{2}=0.9984 \\
D_{L}=\alpha_{L} V_{L}+D^{*}
\end{gathered}
$$

where $D^{*}$ is the effective molecular diffusion coefficient $\left(=\tau D_{0}\right), \alpha_{L}$ is longitudinal dispersivity, $\tau$ is tortuosity of the packed bed (=porosity, $n$ ) and $D_{o}$ is the coefficient of molecular diffusion. Using the analogy of Equation (6) with Equation (7), longitudinal dispersivity $\left(\alpha_{L}\right)$ can be specified for composite sorbent used as PRB in the continuous type of tests.

\subsection{Breakthrough Curves in the Column Tests}

\subsubsection{Inlet Concentration}

The inlet $\mathrm{SO}_{4}{ }^{2-}$ concentration can influence on the propagation of chemical front through the barrier bed at ports $\mathrm{P} 1$ and $\mathrm{P} 2$ was measured for water discharge of $5 \mathrm{~mL} / \mathrm{min}$ (Figure 7a,b). At lower inlet concentration, the curve is less pronounced because the sorption process occurs at the slow rate. Change of $\mathrm{SO}_{4}{ }^{2-}$ concentration from 50 to 100 or $150 \mathrm{mg} / \mathrm{L}$ can accompany a significant increase in the slope of the curve, and this leads to the saturation of the composite sorbent bed in a short period of time. Measurements illustrated that the lower gradient of concentration results in a slower transfer of contaminant towards the sorbent pores due to a reduction in the mass transfer coefficient [61], which increases the breakthrough and saturation times to $5 \%$ and $90 \%$ of the normalization concentration $\left(C / C_{0}\right)$, respectively. Figure $7 \mathrm{a}, \mathrm{b}$ shows that the mentioned times are increased with decreasing inlet concentration; so, this can be accompanied with a significant increase in adsorbed quantities of the $\mathrm{SO}_{4}{ }^{2-}$ ions within the applied bed [62]. For example, the values of breakthrough time for 50, 100 and $150 \mathrm{mg} / \mathrm{L}$ at P1 are 137, 98 and $75 \mathrm{~min}$, respectively, while they increased to be 461,298 and $225 \mathrm{~min}$, respectively, at P2 for water discharge of $5 \mathrm{~mL} / \mathrm{min}$. 

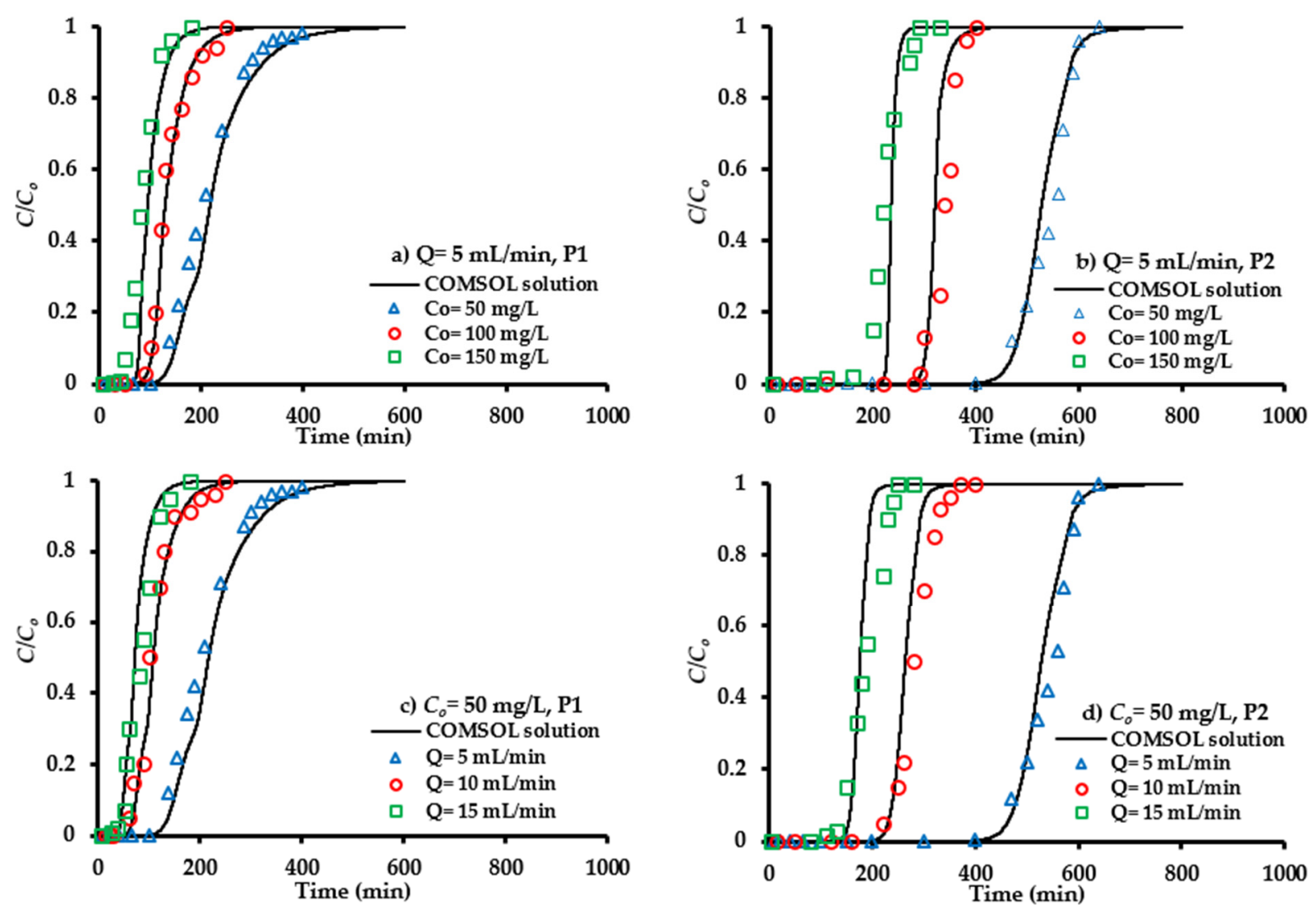

Figure 7. COMSOL outcomes and measurements for the $\mathrm{SO}_{4}{ }^{2-}$ ions normalized concentration at various magnitudes of inlet concentrations $(\mathbf{a}, \mathbf{b})$ and flow rates $(\mathbf{c}, \mathbf{d})$ for P1 and P2 ports.

\subsubsection{Flow Rate of Contaminated Water}

The effect of water flow rate on the migration of $\mathrm{SO}_{4}{ }^{2-}$ ions along the composite sorbent bed was monitored by applying three values, specifically 5,10 and $15 \mathrm{~mL} / \mathrm{min}$. Breakthrough curves (normalized concentration as function of elapsed time) under the effect of flow rate variation are plotted in Figure $7 \mathrm{c}, \mathrm{d}$ at an influent concentration of $50 \mathrm{mg} / \mathrm{L}$ for ports P1 and P2. It is clear that the increase of flow rate can reduce the time required to reach breakthrough point and this will create steeper curves. This reduction in breakthrough time means that the contaminant will leave the packed bed before reaching the equilibrium status [63]. The higher discharge for the same cross sectional area is associated with an increase in the velocity of flow and this can decrease the attachment of $\mathrm{SO}_{4}{ }^{2-}$ ions onto the sorbent surface; therefore, an obvious reduction in removal percentage is observed [64]. Furthermore, the higher flow rate could potentially desorb some of sorbed solute; therefore, the $\mathrm{SO}_{4}{ }^{2-}$ ions increase rapidly, leading to an earlier breakthrough time. The present results are in line with those mentioned in previous literatures [62,65].

\subsubsection{Sorbent Quantity}

Figure 7 illustrates the influence of bed height on the propagation of the contaminant front. For certain inlet concentration and flow rate, measurements proved that the change of bed height from 20 (P1) to $50 \mathrm{~cm}$ (P2) will delay the migration of contaminant, because the higher mass of the sorbent leads to the higher capacity of adsorption. This will be associated with an increase in the breakthrough time and effluent volume; so, breakthrough curves take the typical S-shape graph. In continuous experiments, the sorbent will be exhausted when the influent solution leaves the bed without remarkable remediation. The time lapse taken to attain this exhaustion stage is called "exhaust time". It seems, from the mentioned figure, that the exhaust time of a bed increases with increasing bed height because there 
are more sites for adsorption. However, the capacities of adsorption are decreased with increasing sorbent mass, resulting in the overlap of binding sites [65].

\subsubsection{Treatment of Real Groundwater Sample}

To evaluate the ability of the column packed with prepared sorbent to remediate real groundwater contaminated with $\mathrm{SO}_{4}{ }^{2-}$ ions, samples of water were withdrawn from wells on 1 April 2021. The measured characteristics of this sample, specifically $\mathrm{pH}, \mathrm{EC}, \mathrm{TDS}$, TSS, $\mathrm{SO}_{4}{ }^{2-}, \mathrm{Ca}^{2+}$ and $\mathrm{Mg}^{2+}$, are listed in Table 3, which also explains their values after treatment process. The water sample was treated by injection through a column packed with $50 \mathrm{~cm}$ depth of scrap iron $+\mathrm{AC}-(\mathrm{Mg} / \mathrm{Fe})-\mathrm{LDH}$, at a flowrate of $5 \mathrm{~mL} / \mathrm{min}$, for a contact time of $400 \mathrm{~min}$. It seems that the concentration of $\mathrm{SO}_{4}{ }^{2-}$ ions measured for evaluation of water quality in this study was decreased drastically from 2301 to $709 \mathrm{mg} / \mathrm{L}$, with removal efficiency approximately equal to $70 \%$. This is considered a good result, especially as the influent was real contaminated groundwater. To attain a concentration of $\mathrm{SO}_{4}{ }^{2-}$ ions that is less than the acceptable limit $(250 \mathrm{mg} / \mathrm{L})$, the depth of reactive material must either increase or the flow rate can decrease to simulate the actual velocity of groundwater.

Table 3. Values of popular characteristics for real groundwater samples before and after interaction with composited sorbent prepared in this work in column mode operation.

\begin{tabular}{ccc}
\hline Parameter & Raw Groundwater & Treated Groundwater \\
\hline $\mathrm{pH}$ & 7 & 8.3 \\
\hline $\mathrm{EC}(\mu \mathrm{S} / \mathrm{cm})$ & 5770 & 4561 \\
\hline $\mathrm{TDS}(\mathrm{mg} / \mathrm{L})$ & 1220 & 1170 \\
\hline $\mathrm{TSS}(\mathrm{mg} / \mathrm{L})$ & 21 & 16 \\
\hline $\mathrm{SO}_{4}{ }^{2-}(\mathrm{mg} / \mathrm{L})$ & 2801 & 709 \\
\hline $\mathrm{Ca}^{2+}(\mathrm{mg} / \mathrm{L})$ & 370 & 188 \\
\hline $\mathrm{Mg}^{2+}(\mathrm{mg} / \mathrm{L})$ & 34 & 29 \\
\hline
\end{tabular}

\subsubsection{Hydraulic Conductivity}

Coefficients of hydraulic conductivity of the composite sorbent (i.e., scrap iron +AC$(\mathrm{Mg} / \mathrm{Fe})-\mathrm{LDH})$ bed in the experimental column were determined under different inlet concentrations and flow rates using Darcy's law. The coefficients had values that were approximately constant $\left(\approx 3.3 \times 10^{-2} \mathrm{~cm} / \mathrm{s}\right)$ during the period of each experiment. This indicates that the interconnected pores (i.e., effective porosity of bed) did not change through the operation process.

\subsubsection{Numerical Modelling}

The solute equation was solved by numerical method using COMSOL Multiphysics 3.5a (2008) program (developed by Royal Institute of Technology in Stockholm, Sweden, 2005). The input constants required to achieve this solution can be summarized as follows: Bed depth $=50 \mathrm{~cm}$, porosity $=0.45$, dispersivity $\left(\alpha_{\mathrm{L}}\right)=3.7386 \mathrm{~cm}$ and bulk density $\left(\rho_{b}\right)=1.171 \mathrm{~g} / \mathrm{cm}^{3}$. The zero concentration was the initial condition everywhere along the packed bed, while the concentration of $50 \mathrm{mg} / \mathrm{L}$ and advective flux at input and output bed, respectively, can be the boundary conditions. The solution was implemented for a one-dimensional unsteady state case to determine the contaminant concentrations along the sorbent bed. The solid lines in Figure 7 represent the breakthrough curves predicted from the COMSOL program in comparison with measurements that appeared in the symbols shape. Acceptable matching can recognize between measurements and COMSOL predictions with $\mathrm{R}^{2}$ exceeding 0.98 for the operational condition under consideration.

The verified model represents an efficient tool to predict the migration of $\mathrm{SO}_{4}{ }^{2-}$ ions under different operational conditions, in order to find the longevity of PRB able to attain the concentrations of contaminant with acceptable limits. In this regard, the magnitude 
of the groundwater velocity in practice is much less than that proposed in the experiments conducted; therefore, one additional contaminant interstitial velocity of $0.2 \mathrm{~cm} / \mathrm{min}$ corresponding to a flow rate of $1 \mathrm{~mL} / \mathrm{min}$ for the packed column under consideration was examined. Figure 8 presents a comparison between temporal distributions of the contaminant front for ports $\mathrm{P} 1$ and $\mathrm{P} 2$ due to a decrease of pore velocity $(\mathrm{V})$ from $1 \mathrm{~cm} / \mathrm{min}$ (flow rate $(\mathrm{Q})=5 \mathrm{~mL} / \mathrm{min}$ ) to $0.2 \mathrm{~cm} / \mathrm{min}$. It is clear that there is a delay in the migration of the contaminant front due to a decrease of velocity which causes a significant increase in the longevity of the barrier. The curve corresponding to pore water velocity of $1 \mathrm{~cm} / \mathrm{min}$ is obviously more extended upward than that with $0.2 \mathrm{~cm} / \mathrm{min}$; this is due to the early emergence of the contaminant. The breakthrough times for ports P1 and P2 (Figure 8) at $\mathrm{V}=1 \mathrm{~cm} / \mathrm{min}$ were equal to 137 and $461 \mathrm{~min}$, respectively; however, these times were increased drastically at $\mathrm{V}=0.2 \mathrm{~cm} / \mathrm{min}$ to be 700 and $2355 \mathrm{~min}$, respectively.
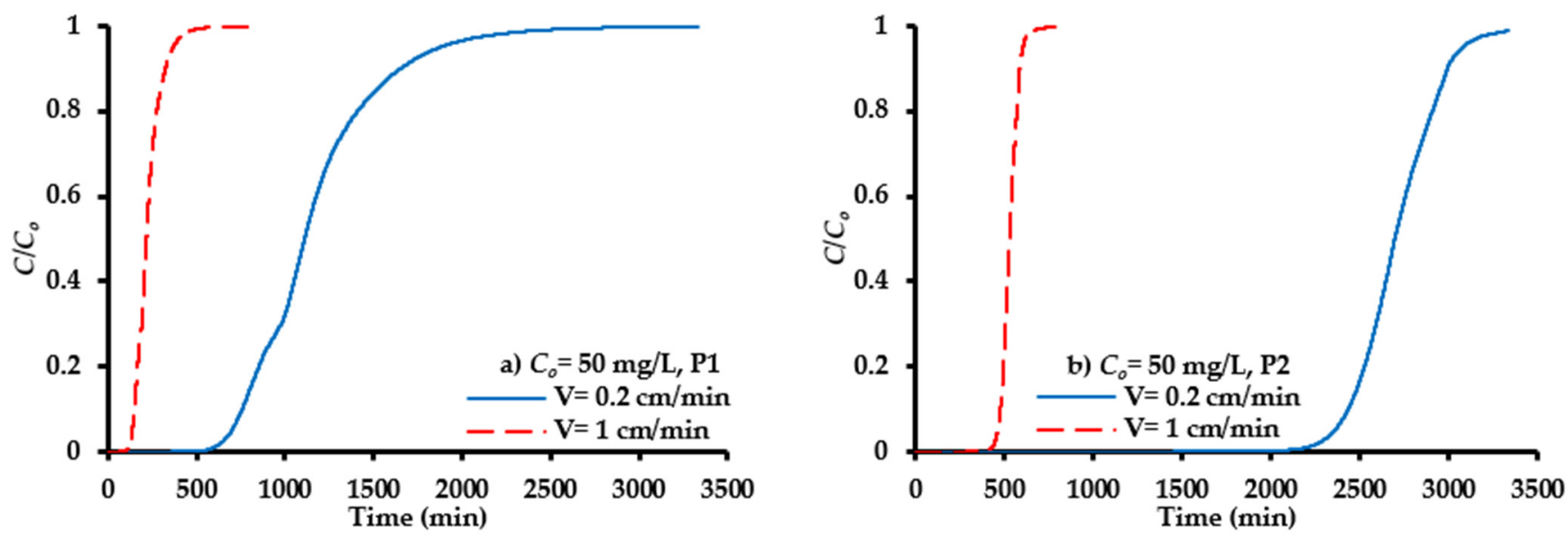

Figure 8. COMSOL prediction for propagation of $\mathrm{SO}_{4}{ }^{2-}$ ions front under variation of pore water velocity for ports (a) P1 and (b) P2.

\section{Materials and Methods}

\subsection{Groundwater Quality}

The quality of groundwater is of nearly equal importance to quantity. The resource cannot be optimally used and sustained unless the quality of groundwater is assessed [66]. The quality of deep groundwater in the Faddak farm was evaluated by measuring the concentrations of $\mathrm{SO}_{4}{ }^{2-}$ ions, which were chosen as the target contaminant in this investigation. Water samples were collected from mentioned wells within the study area during 2019 using test tubes. Measurements of $\mathrm{SO}_{4}{ }^{2-}$ ions were conducted immediately beyond the taking of samples in all experiments of this work at the holy Karbala Province, Karbala Sewage directorate, Iraq using UV spectrophotometer (Shimadzu Model: UV/VIS-1650, Japan). The procedure announced in the Standard Methods for the Examination of Water and Wastewater (METHOD 9038, SULFATE (TURBIDIMETRIC)) was used to measure the concentration of $\mathrm{SO}_{4}{ }^{2-}$ ions [67]. According to $\mathrm{WHO}$ specifications, the permissible contaminant level of $\mathrm{SO}_{4}{ }^{2-}$ for livestock and poultry must be equal to $250 \mathrm{mg} / \mathrm{L}$ [68]. The calibration curve between the absorbance and sulfate concentration was linear with a range from 10 to $1000 \mathrm{mg} / \mathrm{L}$. The limit of quantification (LOQ) and limit of detection (LOD) were calculated by $10 \mathrm{r} / \mathrm{S}$ and $3.3 \mathrm{r} / \mathrm{S}$, respectively, where $\mathrm{S}$ is the calibration curve slope and $\mathrm{r}$ is the standard deviation of the regression equation $(n=10)$. Results proved that the LOQ and LOD had values equal to 0.035 and $0.011 \mathrm{mg} / \mathrm{L}$ respectively.

\subsection{Materials}

The AC was supplied from the Iraqi market with initial porosity of 0.43 (measured by evaporation method) and specific gravity of 1.211. The size distribution of particles for this material was varied from 0.6 to $1 \mathrm{~mm}$. Initially, two sorption tests were applied for finding 
the ability of $\mathrm{AC}$ in the elimination of $\mathrm{SO}_{4}{ }^{2-}$ ions from contaminated water at a speed of $200 \mathrm{rpm}, \mathrm{C}_{0}$ of $50 \mathrm{mg} / \mathrm{L}$, initial $\mathrm{pH} \mathrm{7}$, and time of $3 \mathrm{~h}$ for two AC dosages, specifically 1 and $2 \mathrm{~g}$, added to $50 \mathrm{~mL}$ of water. Results proved that the percentages of removal did not exceed $1 \%$. Hence, there is a need to increase the reactivity of this carbon through generating new binding sites. Thus, it was utilized as an immobilized solid matrix and the magnesium $(\mathrm{Mg})$ with iron $(\mathrm{Fe})$ hydroxides were precipitated as "nanoparticles" onto its

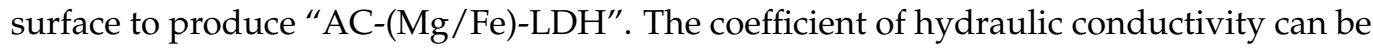
adopted to evaluate the suitability of the composite sorbent to be PRB beside the reactivity.

Due to the high cost of AC [69,70], scrap iron can be tested as a low-cost sorbent to replace a part of the prepared sorbent. The usage of solid wastes in the remediation of contaminated groundwater satisfies the concept of sustainable development. The scrap is generated daily in huge quantities from industrial workshops at Baghdad city capital of Iraq. A statistical survey revealed that the eleven workshops can produce 13.2 ton of scrap per day.

To simulate the water's $\mathrm{SO}_{4}{ }^{2-}$ contamination, a stock solution of $1000 \mathrm{mg} / \mathrm{SO}_{4}{ }^{2-}$ ions were prepared by dissolving $\mathrm{Na}_{2} \mathrm{SO}_{4}$ (obtained from HIMEDIA, India) in one liter of distilled water at room temperature, whereby its $\mathrm{pH}$ could be adjusted to the desirable value by addition of $0.1 \mathrm{M}$ of hydrochloric acid or hydroxide of sodium. The solution with the required concentration of $\mathrm{SO}_{4}{ }^{2-}$ ions was obtained by "dilution process" to use it in the experimental work.

\subsection{Synthesis of Sorbent}

Sorbents with LDHs were manufactured via the co-precipitation procedure at room temperature by applying the same methodology of previous reference [16]. Groups of $200 \mathrm{~mL}$ aqueous solution including $\mathrm{Mg}\left(\mathrm{NO}_{3}\right)_{2} \cdot 6 \mathrm{H}_{2} \mathrm{O}$ and $\mathrm{FeCl}_{3} \cdot 6 \mathrm{H}_{2} \mathrm{O}$, with various weight ratios of $(\mathrm{Mg} / \mathrm{Fe})(10 / 0,7.5 / 2.5,5 / 5,2.5 / 7.5,0 / 10)$, were mixed under agitation with $20 \mathrm{~g}$ AC to prepare $\mathrm{AC}-(\mathrm{Mg} / \mathrm{Fe})-\mathrm{LDH}$. Drops of $2 \mathrm{M}$ of $\mathrm{NaOH}$ were used to increase the $\mathrm{pH}$ of water to be 12 , beyond agitation for $3 \mathrm{~h}$, to ensure the precipitation of $\mathrm{Mg}$ and $\mathrm{Fe}$ on the surface of AC. The solid particles were isolated on the filter paper and then were washed with deionized water; thereafter, the particles were dried at $80^{\circ} \mathrm{C}$ for $24 \mathrm{~h}$. To prepare the mixed sorbent for elimination of $\mathrm{SO}_{4}{ }^{2-}$ ions, coated $\mathrm{AC}$ was mixed with scrap iron in the different proportion percentages as follows: 100/0, 75/25, 50/50, 25/75, 0/100. The suitability of the final sorbent was detected by measuring the removal efficiency of $\mathrm{SO}_{4}{ }^{2-}$ under different operational conditions.

\subsection{Characterization Analyses}

The examination of crystalline structure for the synthesized sorbent was conducted via X-ray diffraction (XRD) analysis (Siemens X-ray diffractometer, D8 Advance, Bruker, Germany). Analysis of FT-IR specifies the functional groups that enhanced the sorption of $\mathrm{SO}_{4}{ }^{2-}$ ions and this test is important in the identification of predominant mechanisms. Scanning electron microscopy (SEM) with an EDS (XFlash 5010; Bruker AXS Microanalysis, Berlin, Germany) was operated to examine the surficial morphology and topography of sorbent under $21^{\circ} \mathrm{C}$ and relative humidity of $55-60 \%$. The zeta potential of manufactured sorbent was measured by Zeta Potential Analyzer (Zeta-Meter Inc., Harrisonburg, VA, USA).

\subsection{Batch Mode Operation}

Interaction of water contaminated with $\mathrm{SO}_{4}{ }^{2-}$ ions was firstly conducted with AC$(\mathrm{Mg} / \mathrm{Fe})-\mathrm{LDH}$ to specify the best weight ratio of $(\mathrm{Mg} / \mathrm{Fe})$ that must be added to ensure the maximum removal percentage of $\mathrm{SO}_{4}{ }^{2-}$. Thereafter, specification of the percentages of $\mathrm{AC}-(\mathrm{Mg} / \mathrm{Fe})-\mathrm{LDH}$ and scrap iron that must be mixed together was required, along with specification of the highest removal amount that can be adopted in order to identify the suitable values of these percentages. Results stated that the best $(\mathrm{Mg} / \mathrm{Fe})$ weight ratio was $7.5 / 2.5$ and $\mathrm{AC}-(\mathrm{Mg} / \mathrm{Fe})-\mathrm{LDH}$ must be mixed with scrap iron in the proportion ratio 
of 50:50 to obtain the final composite (or mixed) sorbent. To optimize the operational parameters, this sorbent must be tested with various values of agitation time, initial $\mathrm{pH}$, sorbent dosage and initial concentration $\left(C_{0}\right)$. The tests require the preparation of a set of $250 \mathrm{~mL}$ flasks filled with $50 \mathrm{~mL}$ of water containing $50 \mathrm{mg} / \mathrm{L} \mathrm{SO}_{4}{ }^{2-}$ ions. Different masses of sorbent were added and the flasks were stirred at $200 \mathrm{rpm}$ on an orbital shaker (SK-300, Biobase Biodustry (Shandong) Co., China) for $3 \mathrm{~h}$. Then, the solid particles were separated from treated water using filter papers (42, whatman, England).

The residual concentration $\left(C_{e}\right)$ of the $\mathrm{SO}_{4}{ }^{2-}$ remaining in the treated water was measured by UV spectrophotometer. Tests were conducted under $\mathrm{pH}(2-12), C_{o}(50-200 \mathrm{mg} / \mathrm{L})$, and sorbent mass $(m, 0.5-5 \mathrm{~g})$ added to a volume $(V, 50 \mathrm{~mL})$ for duration not greater than $3 \mathrm{~h}$. The following equation can applied to determine the $\mathrm{SO}_{4}{ }^{2-}$ sorbed onto the sorbent $\left(q_{e}\right)[71]$ :

$$
q_{e}=\left(C_{o}-C_{e}\right) \frac{V}{m}
$$

The isotherm can draw between determined $q_{e}$ and $C_{e}$. Additionally, the variations of $q_{e}$ with contact time were established and these kinetic data can be analyzed to specify the predominant mechanism. The efficiency of removal $(R)$ is calculated as follows:

$$
R=\frac{\left(C_{o}-C_{e}\right)}{C_{o}} \times 100
$$

\subsection{Continuous Mode Operation}

The experimental set-up manufactured in this work to investigate the ability of mixed sorbent (i.e., $50 \% \mathrm{AC}-(\mathrm{Mg} / \mathrm{Fe})-\mathrm{LDH}+50 \%$ scrap iron) to trap $\mathrm{SO}_{4}{ }^{2-}$ ions within contaminated groundwater consisted of two acrylic columns. Each column had the dimension: Length equal to $50 \mathrm{~cm}$ and inner diameter of $2.5 \mathrm{~cm}$. Two ports, $\mathrm{P} 1$ and P2, were supplied for each column at 20 and $50 \mathrm{~cm}$, respectively, from the base, as shown schematically in Figure 9. Column tests were used to simulate the movement of chemical in one-dimension to represent the actual situation for operating a barrier where the contaminated water flowed in an upward direction. Effluent normalized concentration of contaminant and barrier permeability were the criteria adopted for evaluating the performance of the reactive media.

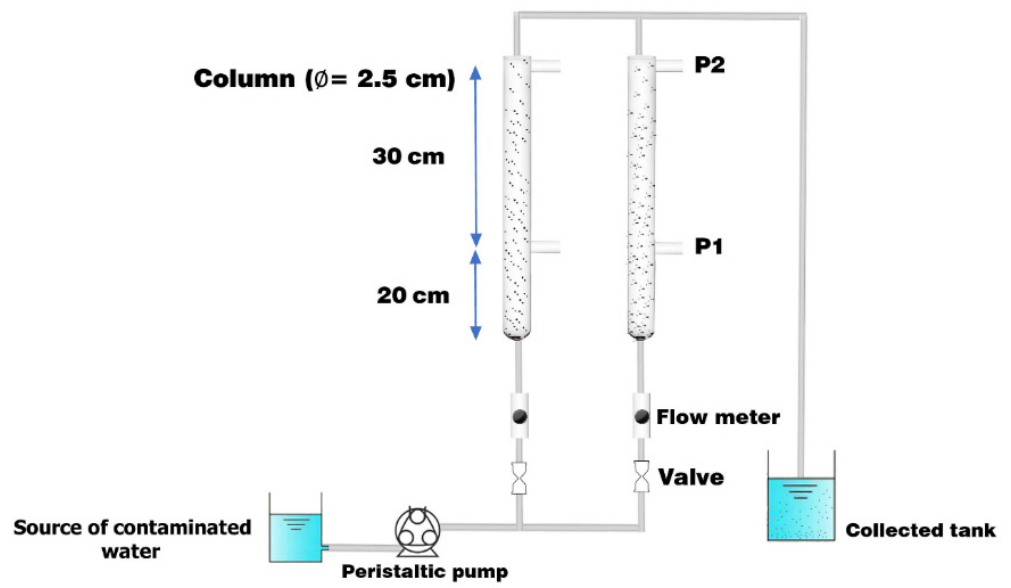

Figure 9. Components of laboratory set-up for continuous mode operation.

The contaminated water was injected by peristaltic pump (Fischer Scientific, FB70382 , Germany) through the column with water discharge of 5,10 , or $15 \mathrm{~mL} / \mathrm{min}$ that was checked using a flow meter. The propagation of $\mathrm{SO}_{4}{ }^{2-}$ ions front was monitored at different values of inlet concentrations (50,100, and $150 \mathrm{mg} / \mathrm{L})$, adsorbent bed heights $(20$ and $50 \mathrm{~cm}$ ) and water flow rates. At specified periods, the samples of water were withdrawn from the mentioned ports using a needle. Additionally, the coefficient of hydraulic conductivity (K) 
was measured by constant head method (ASTM D2434-68) at room temperature [61]. The $\mathrm{K}$ is determined as follows:

$$
\mathrm{K}=\frac{\frac{\mathrm{Q}}{\mathrm{A}}}{\frac{\Delta \mathrm{h}}{\Delta \mathrm{l}}}
$$

where $\mathrm{A}$ is the area of bed-cross section, $\mathrm{Q}$ is the discharge (rate) of flow and $\Delta \mathrm{h}$ is the head difference along the bed length $(\Delta \mathrm{l})$. To measure the longitudinal dispersion coefficient $\left(D_{L}\right)$, the tracer test requires the usage of deionized water containing $1 \mathrm{~g} / \mathrm{L}$ sodium chloride and this water must be pumped to the bed at discharge rates of 5, 10, 15 and $20 \mathrm{~mL} / \mathrm{min}$. The $D_{L}$ is calculated using Equation (11) [72]:

$$
D_{L}=\frac{1}{8}\left[\frac{\left(z_{o}-V t_{0.16}\right)}{\left(t_{0.16}\right)^{0.5}}-\frac{\left(z_{o}-V t_{0.84}\right)}{\left(t_{0.84}\right)^{0.5}}\right]^{2}
$$

where $V$ is the pore velocity, $z_{o}$ is the bed depth (L), while $t_{0.84}$ and $t_{0.16}$ represent the periods required to reach $84 \%$ and $16 \%$ of $C / C_{0}$, respectively.

\section{Conclusions}

To decrease the $\mathrm{SO}_{4}{ }^{2-}$ ions in the groundwater to be less than the acceptable limit, $\mathrm{PRB}$ can be applied by manufacturing new reactive material. This material (consisting of $50 \%$ scrap iron plus $50 \% \mathrm{AC}-(\mathrm{Mg} / \mathrm{Fe})-\mathrm{LDH})$ was efficient in the elimination of these ions with efficiency exceeding $59.0 \%$ for the $\mathrm{Mg} / \mathrm{Fe}$ ratio of $7.5 / 2.5$. Batch tests proved that the best operational conditions for interaction of this sorbent and artificial contaminated water were initial $\mathrm{pH} 5, \mathrm{C}_{0}$ of $50 \mathrm{mg} / \mathrm{L}$, time of $1 \mathrm{~h}$, and sorbent dosage of $2 \mathrm{~g} / 50 \mathrm{~mL}$ at $200 \mathrm{rpm}$. Langmuir and Freundlich models were able to represent the sorption isotherm measurements with $R^{2}$ and SSE of $>0.92$ and $<0.0043$, respectively. The $q_{\max }$ was $9.5 \mathrm{mg} / \mathrm{g}$ and the intensity constant was $0.0028 \mathrm{~L} / \mathrm{mg}$. Outputs of XRD, FT-IR and SEM-EDS tests certified that the $\mathrm{Mg}$ and Fe hydroxides were precipitated on the surface of AC. After coating, the XRD test confirmed the existence of hydrotalcite-like compounds which were composed of $\mathrm{Mg}$ and $\mathrm{Fe}$, while EDS proved the presence of a clear increment in the percentage of these elements. The surface area of AC was equal to $54 \mathrm{~m}^{2} / \mathrm{g}$ and this value could be increased to be $80.3 \mathrm{~m}^{2} / \mathrm{g}$ after coating. Outputs of continuous tests proved that the inlet concentration of $\mathrm{SO}_{4}{ }^{2-}$ ions, rates of flow and depth of bed had a remarkable effect on the shape of the contaminant front. A higher depth with lower rate of flow and inlet concentration can delay the appearance of the $\mathrm{SO}_{4}{ }^{2-}$ front along the length of the bed and this will increase the longevity of the barrier. The prepared sorbent in the column operation mode was effective in the elimination of $\mathrm{SO}_{4}{ }^{2-}$ ions from real contaminated water, with removal efficiency reaching up to $70 \%$. COMSOL can estimate the PRB efficacy due to variation of inlet concentration, bed depth and flow rate, with obvious matching between the numerical predictions and measurements $\left(R^{2} \geq 0.98\right)$.

Author Contributions: Conceptualization, W.H. and A.F.; methodology, E.A.; software, A.F. and E.A.; validation, W.H., A.F. and E.A.; investigation, E.A.; data curation, E.A. and N.A.-A.; writing-original draft preparation, W.H., A.F. and E.A.; writing-review and editing, N.A.-A. and B.S. All authors have read and agreed to the published version of the manuscript.

Funding: This research received no external funding.

Institutional Review Board Statement: Not applicable.

Informed Consent Statement: Not applicable.

Data Availability Statement: The data presented in this study are included in the article. Further inquiries can be directed to the corresponding author. 
Acknowledgments: One of the authors (B. Saleh) is grateful to the Taif University Researchers Supporting Project number (TURSP-2020/49), Taif University, Taif, Saudi Arabia for the financial support. Additionally, the authors (Waqed Hassan, Ayad Faisal, Enas Abed) would like to gratefully acknowledge the technical support of Civil Engineering Department/College of Engineering/University of Kerbala and Faddak Farm/Imam Hussein Holy Shrine during this work.

Conflicts of Interest: The authors declare no conflict of interest.

Sample Availability: Samples of the compounds are not available from the authors.

\section{References}

1. Zhang, X.H. Remediation techniques for soil and groundwater. Point Sources Pollut. Local Eff. Its Control 2009, II, 514.

2. Połoński, M.; Pawluk, K.; Rybka, I. Optimization Model for the Design of Multi-layered Permeable Reactive Barriers. IOP Conf. Ser. Mater. Sci. Eng. 2017, 245. [CrossRef]

3. Sharma, G.; Naushad, M. Adsorptive removal of noxious cadmium ions from aqueous medium using activated carbon/zirconium oxide composite: Isotherm and kinetic modelling. J. Mol. Liq. 2020, 310, 113025. [CrossRef]

4. Faisal, A.A.H.; Al-Wakel, S.F.A.; Assi, H.A.; Naji, L.A.; Naushad, M. Waterworks sludge-filter sand permeable reactive barrier for removal of toxic lead ions from contaminated groundwater. J. Water Process Eng. 2020, 33. [CrossRef]

5. Saad, N.; Abd Ali, Z.T.; Naji, L.A.; Faisal, A.A.A.H.; Al-Ansari, N. Development of Bi-Langmuir model on the sorption of cadmium onto waste foundry sand: Effects of initial $\mathrm{pH}$ and temperature. Environ. Eng. Res. 2020, 25, 677-684. [CrossRef]

6. Faisal, A.A.H.; Abdul-Kareem, M.B.; Mohammed, A.K.; Naushad, M.; Ghfar, A.A.; Ahamad, T. Humic acid coated sand as a novel sorbent in permeable reactive barrier for environmental remediation of groundwater polluted with copper and cadmium ions. J. Water Process Eng. 2020, 36, 101373. [CrossRef]

7. Faisal, A.A.H.; Al-Ridah, Z.A.; Naji, L.A.; Naushad, M.; El-Serehy, H.A. Waste Foundry Sand as Permeable and Low Permeable Barrier for Restriction of the Propagation of Lead and Nickel Ions in Groundwater. J. Chem. 2020, 2020, 1-13. [CrossRef]

8. Ahmed, D.N.; Faisal, A.A.H.; Jassam, S.H.; Naji, L.A.; Naushad, M. Kinetic Model for pH Variation Resulted from Interaction of Aqueous Solution Contaminated with Nickel Ions and Cement Kiln Dust. J. Chem. 2020, 2020, 1-11. [CrossRef]

9. Faisal, A.A.H.; Abdul-Kareem, M.B.; Mohammed, A.K.; Ghfar, A.A. Novel sorbent of sand coated with humic acid-iron oxide nanoparticles for elimination of copper and cadmium ions from contaminated water. J. Polym. Environ. 2021. [CrossRef]

10. Hem, J.D. Study and Interpretation of the Chemical Characteristics of Natural Water, 3rd ed.; United States Geological Survey: Alexandria, Egypt, 1985; Volume 2254, pp. 1-264.

11. Christensen, T.H.; Bjerg, P.L.; Banwart, S.A.; Jakobsen, R.; Heron, G.; Albrechtsen, H.J. Characterization of redox conditions in groundwater contaminant plumes. J. Contam. Hydrol. 2000, 45, 165-241. [CrossRef]

12. Cao, J.; Zhang, G.; Mao, Z.; Fang, Z.; Yang, C. Precipitation of valuable metals from bioleaching solution by biogenic sulfides. Miner. Eng. 2009, 22, 289-295. [CrossRef]

13. Silva, R.; Cadorin, L.; Rubio, J. Sulphate ions removal from an aqueous solution: I. Co-precipitation with hydrolysed aluminumbearing salts. Miner. Eng. 2010, 23, 1220-1226. [CrossRef]

14. Bowell, R. Sulphate and salt minerals: The problem of treating mine waste. Min. Environ. Manag. 2000, 11-14.

15. Alagha, O.; Manzar, M.S.; Zubair, M.; Anil, I.; Mu'azu, N.D.; Qureshi, A. Magnetic Mg-Fe/LDH intercalated activated carbon composites for nitrate and phosphate removal from wastewater: Insight into behavior and mechanisms. Nanomaterials 2020, 10, 1361. [CrossRef] [PubMed]

16. Ahmed, D.N.; Naji, L.A.; Faisal, A.A.H.; Al-Ansari, N.; Naushad, M. Waste foundry sand/MgFe-layered double hydroxides composite material for efficient removal of Congo red dye from aqueous solution. Sci. Rep. 2020, 10, 2042. [CrossRef]

17. Faisal, A.A.H.; Shihab, A.H.; Naushad, M.; Ahamad, T.; Sharma, G.; Al-Sheetan, K.M. Green synthesis for novel sorbent of sand coated with $(\mathrm{Ca} / \mathrm{Al})$-layered double hydroxide for the removal of toxic dye from aqueous environment. J. Environ. Chem. Eng. 2021, 9, 105342. [CrossRef]

18. Lefèvre, G.; Lion, J.; Makolana, A. Extraction of tungsten as polyoxometalate anion using a layered double hydroxide: Selectivity and regeneration. Sep. Sci. Technol. 2018, 54, 549-558. [CrossRef]

19. Hu, H.; Liu, J.; Xu, Z.; Zhang, L.; Cheng, B.; Ho, W. Applied Surface Science Hierarchical porous Ni/Co-LDH hollow dodecahedron with excellent adsorption property for Congo red and Cr(VI)ions. Appl. Surf. Sci. 2019, 478, 981-990. [CrossRef]

20. Tran, H.N.; Lin, C.C.; Woo, S.H.; Chao, H.P. Efficient removal of copper and lead by Mg/Al layered double hydroxides intercalated with organic acid anions: Adsorption kinetics, isotherms, and thermodynamics. Appl. Clay Sci. 2018, 154, 17-27. [CrossRef]

21. Ferreira, O.P.; de Moraes, S.G.; Durán, N.; Cornejo, L.; Alves, O.L. Evaluation of boron removal from water by hydrotalcite-like compounds. Chemosphere 2006, 62, 80-88. [CrossRef]

22. Zhao, D.; Sheng, G.; Hu, J.; Chen, C.; Wang, X. The adsorption of Pb(II) on Mg2Al layered double hydroxide. Chem. Eng. J. 2011, 171, 167-174. [CrossRef]

23. Dore, E.; Frau, F. Antimonate uptake by calcined and uncalcined layered double hydroxides: Effect of cationic composition and M2+/M3+ molar ratio. Environ. Sci. Pollut. Res. 2018, 25, 916-929. [CrossRef] [PubMed] 
24. Gonçalves, R.G.L.; Lopes, P.A.; Resende, J.A.; Pinto, F.G.; Tronto, J.; Guerreiro, M.C.; de Oliveira, L.C.A.; de Castro Nunes, W.; Neto, J.L. Performance of magnetite/layered double hydroxide composite for dye removal via adsorption, Fenton and photo-Fenton processes. Appl. Clay Sci. 2019, 179, 105152. [CrossRef]

25. Gupta, N.K.; Saifuddin, M.; Kim, S.; Kim, K.S. Microscopic, spectroscopic, and experimental approach towards understanding the phosphate adsorption onto Zn-Fe layered double hydroxide. J. Mol. Liq. 2020, 297, 111935. [CrossRef]

26. Zhang, Q.; Ji, F.; Zhao, T.; Shen, Q.; Fang, D.; Kuang, L.; Jiang, L.; Ding, S. Systematic screening of layered double hydroxides for phosphate removal and mechanism insight. Appl. Clay Sci. 2019, 174, 159-169. [CrossRef]

27. Zhu, J.; Zhu, Z.; Zhang, H.; Lu, H.; Zhang, W.; Qiu, Y.; Zhu, L.; Küppers, S. Calcined layered double hydroxides/reduced graphene oxide composites with improved photocatalytic degradation of paracetamol and efficient oxidation-adsorption of As(III). Appl. Catal. B Environ. 2018, 225, 550-562. [CrossRef]

28. Hong, J.; Zhu, Z.; Lu, H.; Qiu, Y. Synthesis and arsenic adsorption performances of ferric-based layered double hydroxide with $\alpha$-alanine intercalation. Chem. Eng. J. 2014, 252, 267-274. [CrossRef]

29. Hudcová, B.; Erben, M.; Vítková, M.; Komárek, M. Antimonate adsorption onto Mg-Fe layered double hydroxides in aqueous solutions at different $\mathrm{pH}$ values: Coupling surface complexation modeling with solid-state analyses. Chemosphere 2019, 229, 236-246. [CrossRef]

30. Ogata, F.; Nagai, N.; Kishida, M.; Nakamura, T.; Kawasaki, N. Interaction between phosphate ions and Fe-Mg type hydrotalcite for purification of wastewater. J. Environ. Chem. Eng. 2019, 7, 102897. [CrossRef]

31. Mandel, K.; Drenkova-Tuhtan, A.; Hutter, F.; Gellermann, C.; Steinmetz, H.; Sextl, G. Layered double hydroxide ion exchangers on superparamagnetic microparticles for recovery of phosphate from waste water. J. Mater. Chem. A 2013, 1, 1840-1848. [CrossRef]

32. Jiang, D.; Yu, Q.; Huang, C.; Chen, S.; Wu, Y.; Lin, J.; Chen, J.; Zhu, P. Preparation of mesoporous spherical magnesium hydroxide particles via the static self-assembled method. J. Mol. Struct. 2019, 1175, 858-864. [CrossRef]

33. Vafaeifard, M.; Ibrahim, S.; Wong, K.T.; Pasbakhsh, P.; Pichiah, S.; Choi, J.; Yoon, Y.; Jang, M. Novel self-assembled 3D flower-like magnesium hydroxide coated granular polyurethane: Implication of its potential application for the removal of heavy metals. J. Clean. Prod. 2019, 216, 495-503. [CrossRef]

34. Wang, Y.; Lin, J.; Wang, Y.; Liu, Z.; Lian, J.; Liu, M. Highly efficient and selective removal of low-concentration antibiotics from aqueous solution by regenerable $\mathrm{Mg}(\mathrm{OH}) 2$. J. Environ. Sci. 2020, 87, 228-237. [CrossRef]

35. Qiu, H.; Ni, W.; Zhang, H.; Chen, K.; Yu, J. Fabrication and evaluation of a regenerable HFO-doped agricultural waste for enhanced adsorption affinity towards phosphate. Sci. Total Environ. 2019, 703, 135493. [CrossRef]

36. Shemer, H.; Armush, A.; Semiat, R. Reusability of iron oxyhydroxide agglomerates adsorbent for repetitive phosphate removal. Colloids Surfaces A Physicochem. Eng. Asp. 2019, 579, 123680. [CrossRef]

37. Drenkova-Tuhtan, A.; Schneider, M.; Franzreb, M.; Meyer, C.; Gellermann, C.; Sextl, G.; Mandel, K.; Steinmetz, H. Pilotscale removal and recovery of dissolved phosphate from secondary wastewater effluents with reusable ZnFeZr adsorbent @ $\mathrm{Fe}_{3} \mathrm{O}_{4} / \mathrm{SiO}_{2}$ particles with magnetic harvesting. Water Res. 2017, 109, 77-87. [CrossRef] [PubMed]

38. Drenkova-Tuhtan, A.; Sheeleigh, E.K.; Rott, E.; Meyer, C.; Sedlak, D.L. Sorption of recalcitrant phosphonates in reverse osmosis concentrates and wastewater effluents-Influence of metal ions. Water Sci. Technol. 2021, 83, 934-947. [CrossRef]

39. Wu, J.; Lin, J.; Zhan, Y. Interception of phosphorus release from sediments using $\mathrm{Mg} / \mathrm{Fe}$-based layered double hydroxide (MF-LDH) and MF-LDH coated magnetite as geo-engineering tools. Sci. Total Environ. 2020, 739, 139749. [CrossRef] [PubMed]

40. Faisal, A.A.H.; Sulaymon, A.H.; Khaliefa, Q.M. A review of permeable reactive barrier as passive sustainable technology for groundwater remediation. Int. J. Environ. Sci. Technol. 2018, 15, 1123-1138. [CrossRef]

41. Tillman, G.M. Water Treatment: Troubleshooting and Problem Solving, 1st ed.; Lewis Publishers: Richmond, VA, USA, 1996; ISBN 978-1575040011. Available online: https://www.amazon.com/Water-Wastewater-Examination-Manual-Adams/dp/0873 711998 (accessed on 27 October 1990).

42. Naushad, M. Surfactant assisted nano-composite cation exchanger: Development, characterization and applications for the removal of toxic $\mathrm{Pb}^{2+}$ from aqueous medium. Chem. Eng. J. 2014, 235, 100-108. [CrossRef]

43. Sharma, G.; Pathania, D.; Naushad, M.; Kothiyal, N.C. Fabrication, characterization and antimicrobial activity of polyaniline Th(IV) tungstomolybdophosphate nanocomposite material: Efficient removal of toxic metal ions from water. Chem. Eng. J. 2014, 251, 413-421. [CrossRef]

44. Al-Ansari, N.; Saleh, S.; Abdullahand, T.; Ali Abed, S. Quality of Surface Water and Groundwater in Iraq. J. Earth Sci. Geotech. Eng. 2020, 11, 161-199. [CrossRef]

45. Al-Jiburi, H.K.; Al-Basrawi, N.H. The Hydrogeology of Iraqi western and southern desert. West. Iraqi Desert J. 2007, 77-91.

46. Zheng, H.; Liu, D.; Zheng, Y.; Liang, S.; Liu, Z. Sorption isotherm and kinetic modeling of aniline on Cr-bentonite. J. Hazard. Mater. 2009, 167, 141-147. [CrossRef] [PubMed]

47. Foo, K.Y.; Hameed, B.H. Insights into the modeling of adsorption isotherm systems. Chem. Eng. J. 2010, 156, 2-10. [CrossRef]

48. Puranik, P.R.; Modak, J.M.; Paknikar, K.M. A comparative study of the mass transfer kinetics of metal biosorption by microbial biomass. Hydrometallurgy 1999, 52, 189-197. [CrossRef]

49. Ho, Y.S.; McKay, G. Pseudo-second order model for sorption processes. Process Biochem. 1999, 34, 451-465. [CrossRef]

50. Liu, J.; Yue, X.; Yu, Y.; Guo, Y. Adsorption of sulfate from natural water on calcined Mg-Fe layered double hydroxides. Desalin. Water Treat. 2015, 56, 274-283. [CrossRef] 
51. Adegoke, H.I.; Adekola, F.A.; Bdulraheem, M.N. Kinetic and thermodynamic studies on adsorption of sulphate from aqueous solution by magnetite, activated carbon and magnetite-activated carbon composites. Niger. J. Chem. Res. 2017, 22, 39-69.

52. Rahmati, M.; Yeganeh, G.; Esmaeili, H. Sulfate ion removal from water using activated carbon powder prepared by Ziziphus Spina-Christi Lotus Leaf. Acta Chim. Slov. 2019, 66, 888-898. [CrossRef]

53. Amarasinghe, B.M.W.P.K.; Williams, R.A. Tea waste as a low cost adsorbent for the removal of $\mathrm{Cu}$ and $\mathrm{Pb}$ from wastewater. Chem. Eng. J. 2007, 132, 299-309. [CrossRef]

54. Faisal, A.A.H.; Alquzweeni, S.S.; Naji, L.A.; Naushad, M. Predominant mechanisms in the treatment of wastewater due to interaction of benzaldehyde and iron slag byproduct. Int. J. Environ. Res. Public Health 2020, 17, 226. [CrossRef] [PubMed]

55. Naji, L.A.; Jassam, S.H.; Yaseen, M.J.; Faisal, A.A.H.; Al-Ansari, N. Modification of Langmuir model for simulating initial pH and temperature effects on sorption process. Sep. Sci. Technol. 2020, 55, 2729-2736. [CrossRef]

56. Namasivayam, C.; Sangeetha, D. Application of coconut coir pith for the removal of sulfate and other anions from water. Desalination 2008, 219, 1-13. [CrossRef]

57. Guo, Y.; Zhu, Z.; Qiu, Y.; Zhao, J. Adsorption of arsenate on $\mathrm{Cu} / \mathrm{Mg} / \mathrm{Fe} / \mathrm{La}$ layered double hydroxide from aqueous solutions. J. Hazard. Mater. 2012, 239-240, 279-288. [CrossRef]

58. Yang, T.; Lua, A.C. Characteristics of activated carbons prepared from pistachio-nut shells by physical activation. J. Colloid Interface Sci. 2003, 267, 408-417. [CrossRef]

59. Gulmine, J.; Janissek, P.; Heise, H.; Akcelrud, L. Polyethylene characterization by FTIR. Polym. Test. 2002, 21, 557-563. [CrossRef]

60. Hesenov, A.; Meryemoğlu, B.; Içten, O. Electrolysis of coal slurries to produce hydrogen gas: Effects of different factors on hydrogen yield. Int. J. Hydrogen Energy 2011, 36, 12249-12258. [CrossRef]

61. Delleur, J. The Handbook of Groundwater Engineering; CRC Press LLC, Springer: Boca Raton, FL, USA, 1999; ISBN 3-540-64745-7.

62. Liao, P.; Zhan, Z.; Dai, J.; Wu, X.; Zhang, W.; Wang, K.; Yuan, S. Adsorption of tetracycline and chloramphenicol in aqueous solutions by bamboo charcoal: A batch and fixed-bed column study. Chem. Eng. J. 2013, 228, 496-505. [CrossRef]

63. Ko, D.C.K.; Porter, J.F.; McKay, G. Optimised correlations for the fixed-bed adsorption of metal ions on bone char. Chem. Eng. Sci. 2000, 55, 5819-5829. [CrossRef]

64. Kundu, S.; Gupta, A.K. As(III) removal from aqueous medium in fixed bed using iron oxide-coated cement (IOCC): Experimental and modeling studies. Chem. Eng. J. 2007, 129, 123-131. [CrossRef]

65. Marzbali, M.H.; Esmaieli, M. Fixed bed adsorption of tetracycline on a mesoporous activated carbon: Experimental study and neuro-fuzzy modeling. J. Appl. Res. Technol. 2017, 15, 454-463. [CrossRef]

66. Todd, D.K.; Mays, L.W. Groundwater Hydrology, 3rd ed.; John Wiley and Sons, Inc.: Hoboken, NJ, USA, 2005; ISBN 978-0-47105937-0.

67. US EPA. Standard Methods for the Examination of Water and Wastewater; American Public Health Association (APHA): Washington, DC, USA, 1975; pp. 1-496.

68. Ayers, R.S.; Westcot, D.W. Water Quality for Agriculture; Irrig. Drain. Pap. 29, Rev. 1; FAO: Rome, Italy, $1994 ;$ pp. 1-130.

69. Faisal, A.A.H.; Ali, I.M.; Naji, L.A.; Madhloom, H.M.; Al-ansari, N. Using different materials as a permeable reactive barrier for remediation of groundwater contaminated with landfill's leachate. Desalin. Water Treat. 2020, 24890, 1-12. [CrossRef]

70. Gupta, V.K. Equilibrium uptake, sorption dynamics, process development, and column operations for the removal of copper and nickel from aqueous solution and wastewater using activated slag, a low-cost adsorbent. Ind. Eng. Chem. Res. 1998, 37, 192-202. [CrossRef]

71. Wang, S.; Dong, Y.; He, M.; Chen, L.; Yu, X. Characterization of GMZ bentonite and its application in the adsorption of Pb(II) from aqueous solutions. Appl. Clay Sci. 2009, 43, 164-171. [CrossRef]

72. Ujfaludi, L. Le comportement de dispersion longitudinale des sols à granulométrie non-uniforme. Hydrol. Sci. J. 1986, 31, 467-474. [CrossRef] 